\title{
The efficiency of curved jetties in Bay of Santos - SP: numerical modeling
}

\section{A eficiência de molhes guia - corrente curvos na Baía de Santos - SP: modelação numérica}

Tiago Zenker Gireli ${ }^{1}$, Camila Maria Mateus Alves de Souza ${ }^{1}$, Larissa Bertholdo Nobre ${ }^{1}$, and Patrícia Dalsoglio Garcia ${ }^{1}$

${ }^{1}$ Universidade Estadual de Campinas, Campinas, SP, Brazil

E-mails: zenker@fec.unicamp.br (TZG),camila.mmas@gmail.com (CMMAS), lbertholdo@gmail.com (LBN),dgpatricia@gmail.com (PDG)

\begin{abstract}
Nowadays, Port of Santos is the largest in Latin America, and it is undergoing a process of deepening of its access channel and, as its final target, is expected to attain $17 \mathrm{~m}$. A considerable increase in the maintenance dredging volume is expected, particularly for the section of the maritime sandbar that is, currently, only maintained by dredging. Consequently, this study employed numerical modeling to propose an efficient layout for two curved, current-guiding jetties for the transposition of the maritime sandbar of Port of Santos navigation channel, and it's evaluated their efficiency in maintaining depths throughout the channel. Therefore, it was used only the hydrodynamic model of Mike 21 to compare the results with the physical modeling realized in the same simulation conditionals. The results indicate, in both approaches, the current velocities increased with the proposal jetties. Thus, the accomplished study indicates that the adoption of permanent constructions for transposition of the maritime sandbar of the Port of Santos is clearly feasible and it could constitute a more economically attractive option for maintaining depths of $17 \mathrm{~m}$ than the current one.
\end{abstract}

Keywords: Costal and Port Engineer; Jetties; Numerical modeling; Dredging.

\section{RESUMO}

Atualmente o Porto de Santos é o maior da América Latina, e encontra-se em processo de aprofundamento de seu canal de acesso prevendo alcançar a profundidade de 17,0 m como meta final. Especificamente para o trecho da barra marítima que hoje é mantida somente por dragagem, espera-se um incremento significativo no volume de dragagem de manutenção. Neste sentido, este trabalho empregou a modelagem matemática para verificar a eficiência da construção de dois molhes guia - corrente curvos para a transposição da barra marítima do canal do Porto de Santos e avaliar sua eficiência na manutenção das profundidades no canal. Foi utilizado o módulo hidrodinâmico do software Mike 21 para que os resultados pudessem ser comparados aos obtidos em modelação física nas mesmas condições de simulação. Os resultados apontaram que, assim como os resultados obtidos em modelo físico, ocorre incremento das velocidades das correntes com a introdução dos molhes propostos indicando ser plenamente viável a adoção de obras fixas para a transposição da barra marítima do Porto de Santos, podendo configurar-se como uma opção economicamente mais atraente do que a atual, para manter profundidades de $17,0 \mathrm{~m}$.

Palavras-chave: Engenharia Costeira e Portuária; Molhes guia-corrente; Modelação numérica; Dragagem. 


\section{INTRODUCTION}

In Brazil there is an increasing concern about port efficiency, as maritime transport is the main means of transporting goods for Brazil's foreign trade.

In 2012, the tonnage exported by sea represented $96 \%$ of the total, while that imported reached $89 \%$. If commercial flow is analyzed by value (\$US FOB), it is evident that this share has increased in recent years, reaching $84 \%$ of the amount exported and $76 \%$ of that imported, in other words, the highest level since 2007 (CNT, 2015).

According to the Global Competitiveness Report 2015-2016, with respect to the quality of port infrastructure, Brazil occupies the $120^{\mathrm{ST}}$ position, behind all the other countries of BRIC (Brazil, Russia, India and China) and also behind Argentina, Mexico and Colombia (SCHWAB, 2015). The inefficiency of its ports is one of Brazil's main problems, harming its productivity and competitiveness.

In the balance of trade, the Santos Port Complex is isolated in the ranking of Brazilian ports with a $25.3 \%$ share of the movement of Brazilian trade. Specifically regarding to the movement of containerized cargo, the Port of Santos handled 3.7 million TEUs in 2014, 6.8\% greater than the traffic in 2013, which earned the Port of Santos 38th position in the 2013 ranking of Container Management Magazine, occupying the best position among Latin American ports and outperforming the port of Balboa, in Panama (CODESP, 2016). Consequently, Santos would be an obvious candidate to become a Hub Port, a port for concentrating cargo from the South Atlantic, providing it manages to overcome certain shortcomings related principally to the efficiency of maritime operations, thereby reducing logistics costs and increasing the competitiveness of Latin-American products in the international market (GIRELI; VENDRAME, 2012).

Port of Santos (Figure 1) is administered by Companhia Docas do Estado de São Paulo (CODESP) [State Dock Company of São Paulo]. With an area of 7.7 million $\mathrm{m}^{2}$ and $13 \mathrm{~km}$ of wharves, the port is located midway along the coast of the State of São Paulo, in an estuary delineated by the islands of São Vicente and Santo Amaro, $2 \mathrm{~km}$ from the Atlantic Ocean. Due to its location, its hinterland concentrates more than $50 \%$ of GDP, includes the states of São Paulo, Mato Grosso do Sul, Mato Grosso, Goiás,

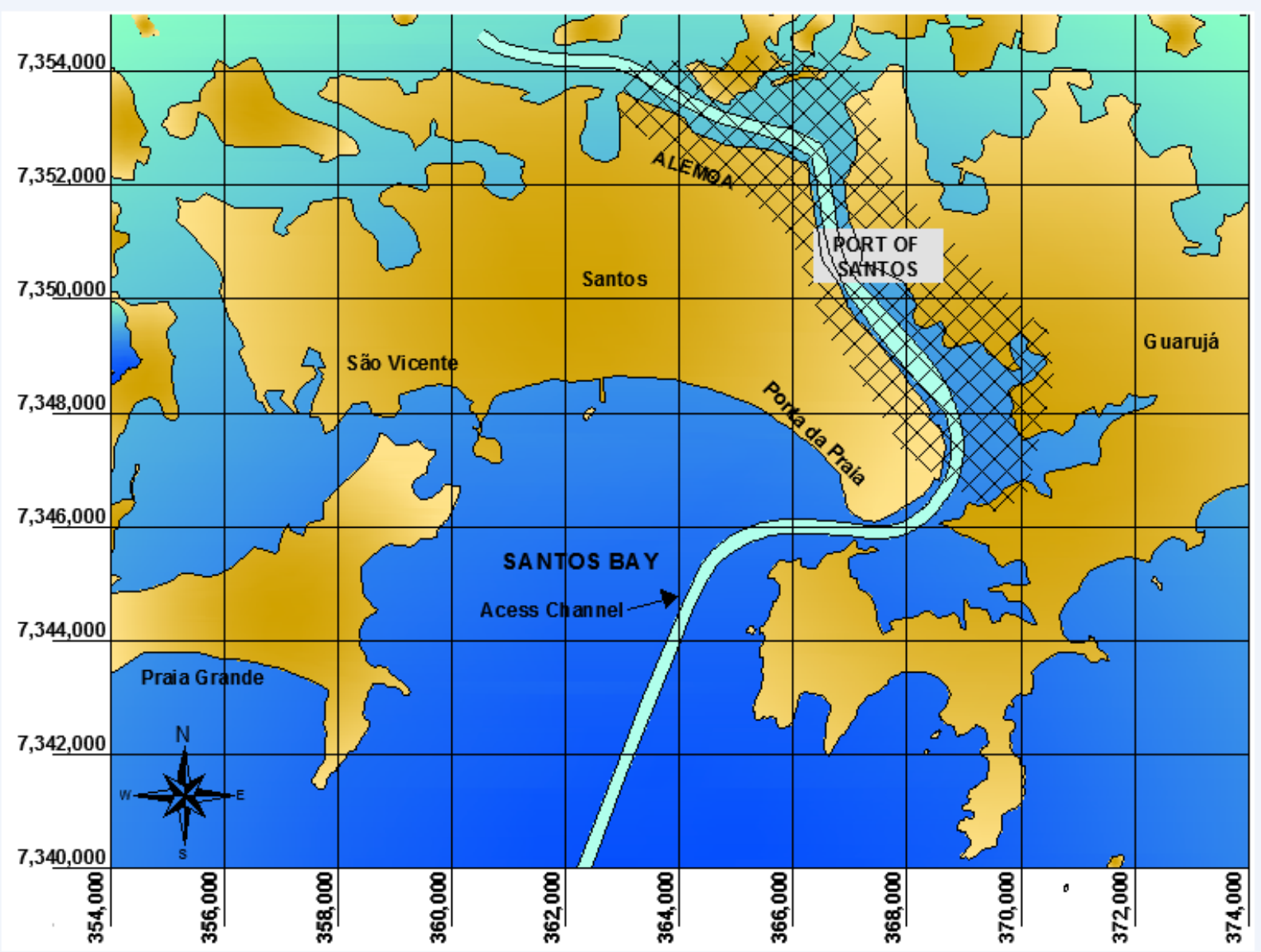

Figure 1. Location of Port of Santos. 
Minas Gerais and Paraná, in addition to its influence in South America. The Santos' city is also located at a strategic point in the State of São Paulo, around $90 \%$ of the industrial base of the State of São Paulo is less than 200 kilometers from the Port of Santos according to the National Transport Federation (BRASIL, 2015).

According to CODESP (2015), since January 2015 the Santos navigation channel has been dredged up to an average depth of $15.0 \mathrm{~m}$ and it has an authorized draft of $13.2 \mathrm{~m}$ up to Alemoa region. This depth increase (previously $13.3 \mathrm{~m}$ ) is part of the first work phase for deepening the Port envisaged in the National Dredging Program (PND), using funds from the Growth Acceleration Program (PAC) of the Federal Government. The goal is reaching a depth of $17 \mathrm{~m}$ until 2020. The objective of this depth is to allow the port to attract Post-Panamax class ships, whose draft can reach $14.4 \mathrm{~m}$. Similarly, the widening of the port channel was recently completed, with the minimum width increasing from $150 \mathrm{~m}$ to $200 \mathrm{~m}$, allowing greater cargo movement. However, the dredging work does not have a permanent effect; in other words, sediments will be naturally deposited in the port channel once again.

Along the entire length of the Port of Santos access channel, the maritime sandbar sector is the most affected by the process of silting as a result of wave action and the lack of flow containment, and it is responsible for about $60 \%$ of the volume dredged annually, to maintain depths in the port (GIRELI; VENDRAME, 2012).

According to Gireli and Vendrame (2012), the volume dredged to maintain the depth of $15 \mathrm{~m}$ in this section is estimated at 3.2 million cubic meters per year, with an average rate of change of $1.34 \mathrm{~m} /$ year. This rate is almost $140 \%$ higher than that registered before the deepening. According to the study, the approximate cost of dredging to maintain a depth of $15 \mathrm{~m}$ in the channel is $\mathrm{R} \$ 30$ million annually. In addition, after storm surges, the dredgers could take days or weeks to return the channel to its specified level, temporarily preventing larger draft ships from entering and causing serious losses for the port.

In the past, the marine sandbar transposition using permanent constructions was studied and rejected because, for standard drafts of ships that used to access the port at that time, the option of maintenance solely by dredging was shown to be more attractive economically. However, with the adoption of Post-Panamax as the new standard ship for the Port of Santos and the need to reach $17 \mathrm{~m}$ DHN of depth, the adoption of jetties may become a feasible option.

Reis (1978) analyzed six different designs of jetties in physical model with mobile bed. The purpose of the study was to reduce the large volume of sediment that used to be necessary to be dredged annually to keep $14 \mathrm{~m}$ of depth in the marine stretch of the navigation channel. The first two proposals were omitted because they resulted less effective than the others. The proposals 3 to 6 are shown in Figure 2 and the main conclusions obtained by the author were:
$3^{\text {rd }}$ option: the thalweg of the channel tends to divert to southeast, changing curvature radius and losing the ability to flush out sediments during ebb tide;

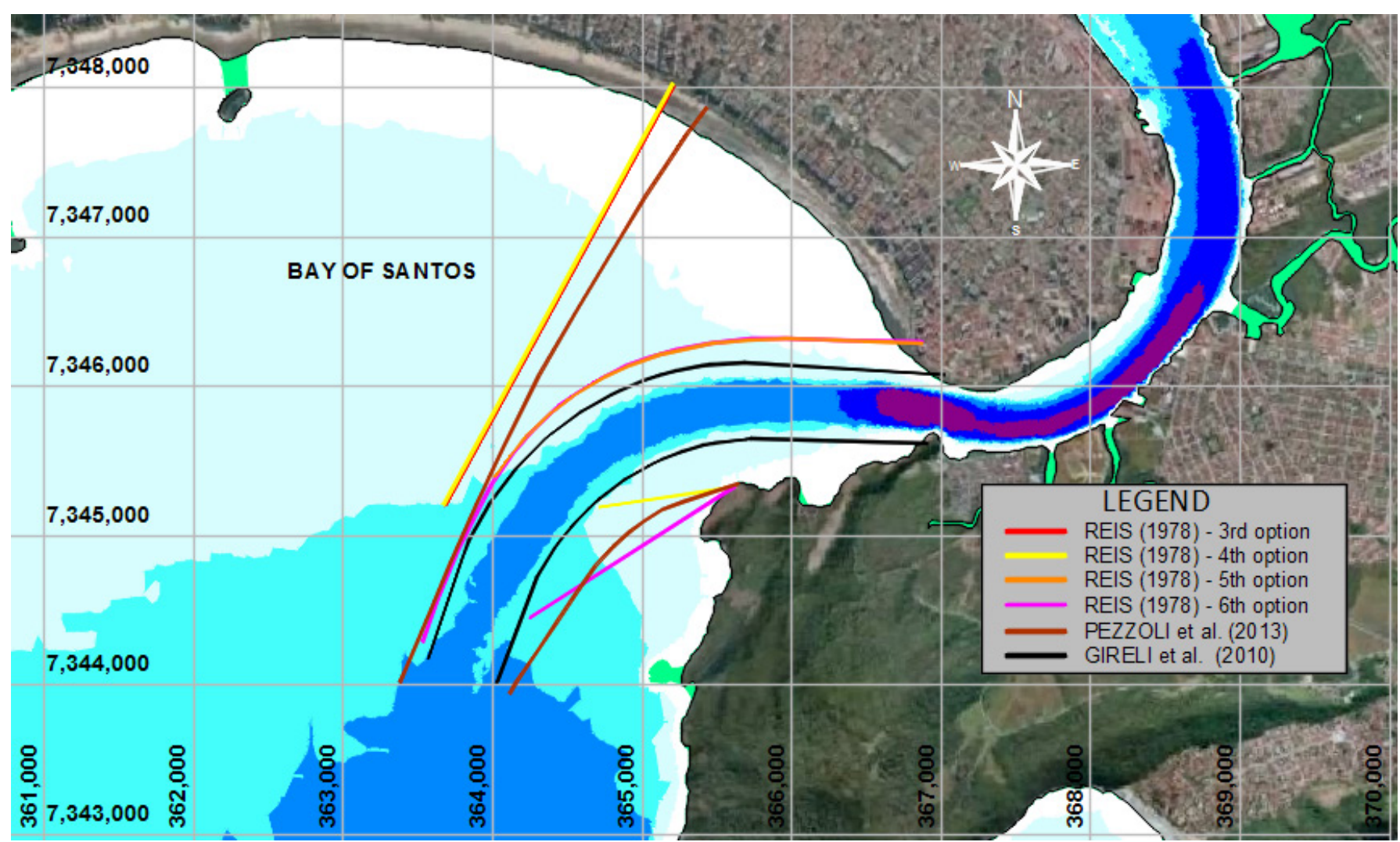

Figure 2. Existing proposals of jetties for Port of Santos marine Sandbar transposition. 
$4^{\text {th }}$ option: the presence of the second jetty improved the channel ability of flushing out the sediments during ebb tide, but the divert of the channel still could be noticed;

$5^{\text {th }}$ option: the curved jetty embanked on Ponta da Praia region was not able to prevent the occurrence of a marked deviation from the navigation channel axis;

$6^{\text {th }}$ option: the extension of the curved jetty as far as the $11 \mathrm{~m}$ isobath and the addiction of a second jetty, straight and embanked on the other side of the mouth resulted in the best proposal according to the author. Nonetheless, a siltation near to the curved jetty and a deviation of the channel thalweg toward the head of the straight jetty were detected.

More recently, two new designs of jetties were proposed. One developed by Gireli et al. (2010), other presented by Pezzoli et al. (2013). Both were designed aiming to keep $17 \mathrm{~m}$ of depth on the navigation channel of Port of Santos.

Pezzoli et al. (2013) emphasized that permanent constructions are greatly important for maintaining the depth of the Port of Santos and they proposed a strongly converging layout for the jetties (Figure 2). However, Reis (1978) concluded that for configurations like Pezzoli et al. (2013) proposal, the axis of the channel-bed tends to become displaced, which would generate problems for navigation. In addition, creating the foundations of the straight breakwater proposed by Pezzoli et al. (2013) would have a strong impact on a stretch of more than 2 kilometers of Santos coastline, which could make the adoption of this alternative impossible in a future environmental licensing process.

On the other hand, Gireli et al. (2010) proposed two strongly curved and slightly converging jetties (Figure 2). This study used a physical model with a fixed bed, scale of 1:1200 in the horizontal and 1:200 in the vertical, which was dynamic and capable of reproducing waves and tides (Figure 3).

Gireli et al. (2010) results indicated that the proposed jetties are efficient in maintaining depths throughout the navigation channel. Although, the authors highlighted the importance of the realization of studies using numerical modeling to corroborate the study and to refine the build proposal.

In addition to the port issues, there is a considerable ongoing and polemical discussion about the actual causes of erosion at Ponta da Praia (see Figure 2). It is located close to the mouth of the Santos estuary which is crossed by the navigation channel and, supposedly, impacted by dredging in recent years. This erosion

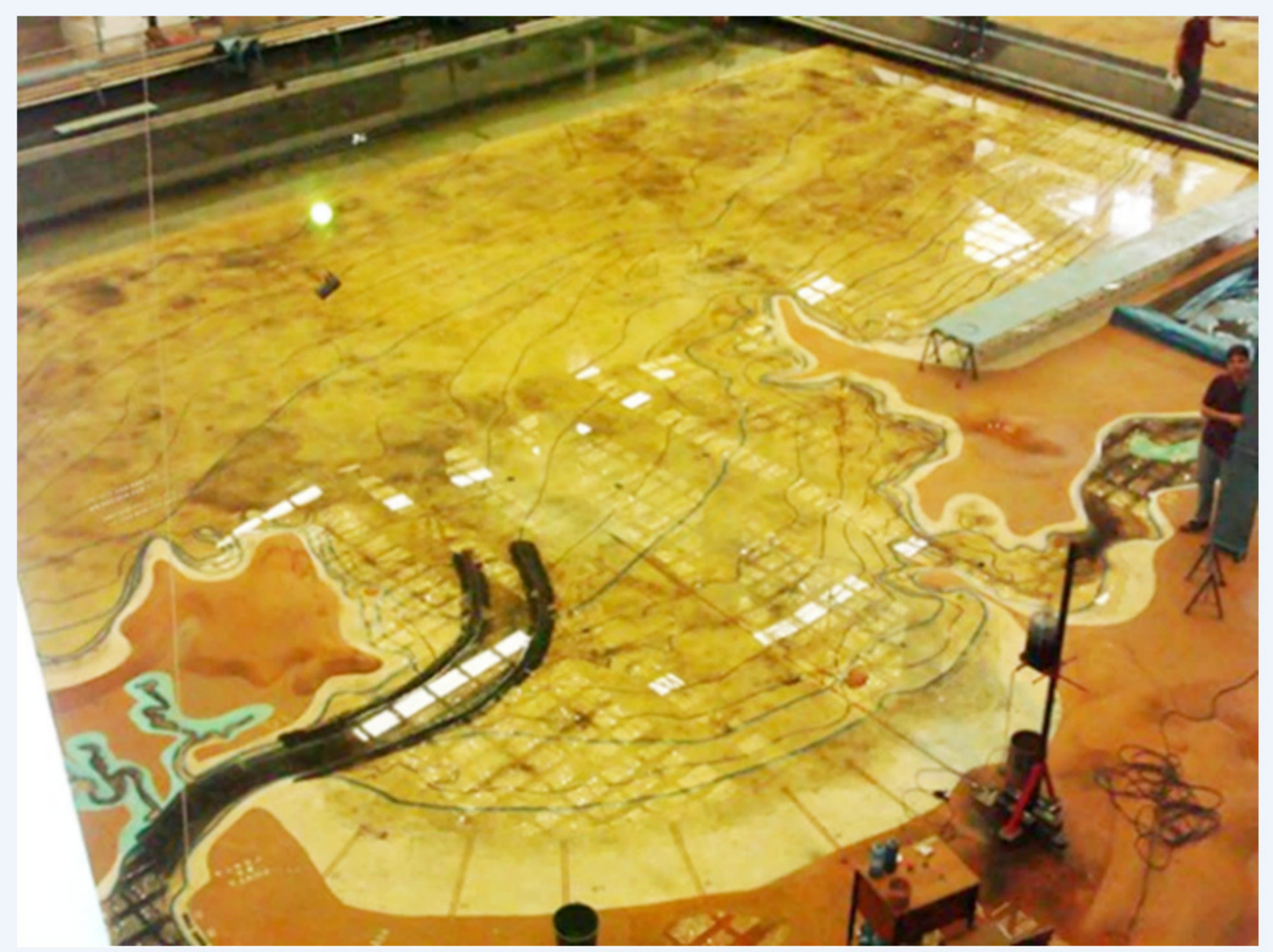

Figure 3. Physical model of the Bay and Estuary of Santos and São Vicente with Gireli et al. (2010) proposed jetties. Source: Gireli et al. (2010). 
greatly intensified from 2010 onwards, when the work to deepen and widen the Port's channel began. This polemic topic has been discussed in media sources and according to them, Public Ministry filled a civil action against CODESP in the 2015 because of the erosion at Ponta da Praia (G1 SANTOS, 2015).

Thus, considering the intention of reach $17 \mathrm{~m}$ of depth in the port channel and the need to intervene to protect the Ponta da Praia region from the erosion process, this study employed numerical modeling to evaluate the jetties planned by Gireli et al. (2010) for the transposition of the maritime sandbar of the Port of Santos channel, and its efficiency in maintaining depths throughout the channel. The numerical model used was developed by Souza (2012) and here was applied only with the hydrodynamic model to keep the same conditions of the simulations using the physical modeling (GIRELI et al., 2010). Thus, it was possible compare the results.

\section{MATERIALS AND METHODS}

The jetties efficiency analysis was done by numerical modeling of Santos Bay and Estuary which was planned by Souza (2012). This model was calibrated for the current conditions, without jetties.

AutoCad Civil 3D software has been used to change the Santos original bathymetry, creating different surveys by the introduction of the jetties, deepening and widening the navigation channel.

The two curved jetties introduced in the model were the same proposed by Gireli et al. (2010). Moreover, the tidal levels and the rivers flow in the estuary were extract from Sondotécnica (1977a, b), and applied by Souza and Gireli (2012). Finally the others parameters advised by DHI (2011) were kept in all of proposed scenarios.

It was proposed three different scenarios:

- Scenario 1: original scenario proposed by Souza (2012), without jetties, like Gireli et al. (2010) original scenario;

- Scenario 2: original scenario proposed by Souza (2012), inserting jetties, like Gireli et al. (2010) proposed scenario;

- Scenario 3: scenario proposed by Souza (2012), inserting jetties and changing the depths of the access channel (see Figure 1) to $17,0 \mathrm{~m} \mathrm{DHN}$ and wide to $200 \mathrm{~m}$, just like the future access channel target template.

\section{The hydrodynamic model}

The numerical modeling technique has been successfully applied in many studies to represent coastal environments (HARARI; CAMARGO, 1998; BAPTISTELLI, 2008; ROVERSI et al., 2016). The complex hydrodynamic effects which include salinity and temperature stratification would require a 3D modeling. However, there is a lack of vertical discretized field data to calibrate this kind of model, besides, the 3D modeling demands a lot of computation resources. Therefore, it was applied a $2 \mathrm{D}$ hydrodynamic modeling to develop this study.
The Santos modeling was done with Mike 21 FM software, developed by DHI (2011) which provided a time limited license for thesis.

Mike 21 FM is a two-dimensional hydrodynamic model which uses finite method solution with shallow water equations (DHI, 2011). The equations of conservation of mass and momentum integrated over the vertical describe the flow and the water level variations, as following:

$\frac{\partial \zeta}{\partial t}+\frac{\partial p}{\partial x}+\frac{\partial q}{\partial y}=0$

$\frac{\partial p}{\partial t}+\frac{\partial}{\partial x}\left(\frac{p^{2}}{h}\right)+\frac{\partial}{\partial y}\left(\frac{p q}{h}\right)+g h \frac{\partial \zeta}{\partial x}+\frac{g p \sqrt{p^{2}+q^{2}}}{C^{2} \cdot h^{2}}-$

$\frac{1}{\rho_{w}}\left[\frac{\partial}{\partial x}\left(h \tau_{x x}\right)+\frac{\partial}{\partial y}\left(h \tau_{x y}\right)\right]-\Omega p-f V V_{x}+\frac{h}{\rho_{w}} \frac{\partial}{\partial x}\left(p_{a}\right)=0$

$\frac{\partial q}{\partial t}+\frac{\partial}{\partial y}\left(\frac{q^{2}}{h}\right)+\frac{\partial}{\partial x}\left(\frac{p q}{h}\right)+g h \frac{\partial \zeta}{\partial y}+\frac{g p \sqrt{p^{2}+q^{2}}}{C^{2} \cdot h^{2}}-\frac{1}{\rho_{w}}\left[\begin{array}{l}\frac{\partial}{\partial y}\left(h \tau_{y y}\right)+ \\ \frac{\partial}{\partial x}\left(h \tau_{x y}\right)\end{array}\right]+\Omega p$

$b(x, y, t)$ - water depth.

$\zeta$ - surface elevation.

$p, q$ - flux densities in $\mathrm{x}$ and $\mathrm{y}$ directions.

$C(x, y)$ - Chezy resistance.

$g$ - acceleration due to gravity.

$f(V)$ - wind friction factor.

$V, V_{x}, V_{y}$ - wind speed and components in $x$ and $y$ directions.

$\Omega$ - Coriolis parameter.

$p_{a}(x, y, t)$ - atmospheric pressure.

$\varrho_{w}$ - density of water

$x, y$ - space coordinates

$t$ - time.

$\tau_{x x}, \tau_{x y}, \tau_{y y}$ - components of effective shear stress.

The bathymetric database used in Scenario 1 (Figure 4) was the same used to built the physical model where Gireli et al. (2010) had led their study. It is a mosaic of bathymetric information extracted from: DHN - Diretoria de Hidrografia e Navegação; CTH - Centro Tecnológico de Hidráulica e Recursos Hídricos - Escola Politécnica da USP (CTH, 1976, 1968); and CODESP- Companhia Docas do Estado de São Paulo.

For Scenario 2, the original bathymetric database was modified by introducing the jetties proposed by Gireli et al. (2010). These changes were made using Autodesk Civil 3D software and export to Mike 21 (Figure 5)

For Scenario 3, it was made the same changes for scenario 2. In addition, the depths of Santos Port access channel were artificially changed to $17,0 \mathrm{~m}$ DHN using Autodesk Civil 3D software. It was adopted a 1:3 slope to accommodate the vertical differences between the real bathymetry and the artificial depth along the access channel, simulating a real dredging. Finally, the modified bathymetric survey was exported to Mike 21 (Figure 6).

Tidal currents are responsible for $70 \%$ of all circulation current in Santos Estuary (SONDOTÉCNICA, 1977a). This is the reason to consider mainly tide effects to induce the currents in the hydrodynamic model, neglecting waves and wind effects. It also makes numerical simulation similar to the physical one. On the other hand, it was considered the rivers flow in the estuary, which is the second important effect to induce currents 


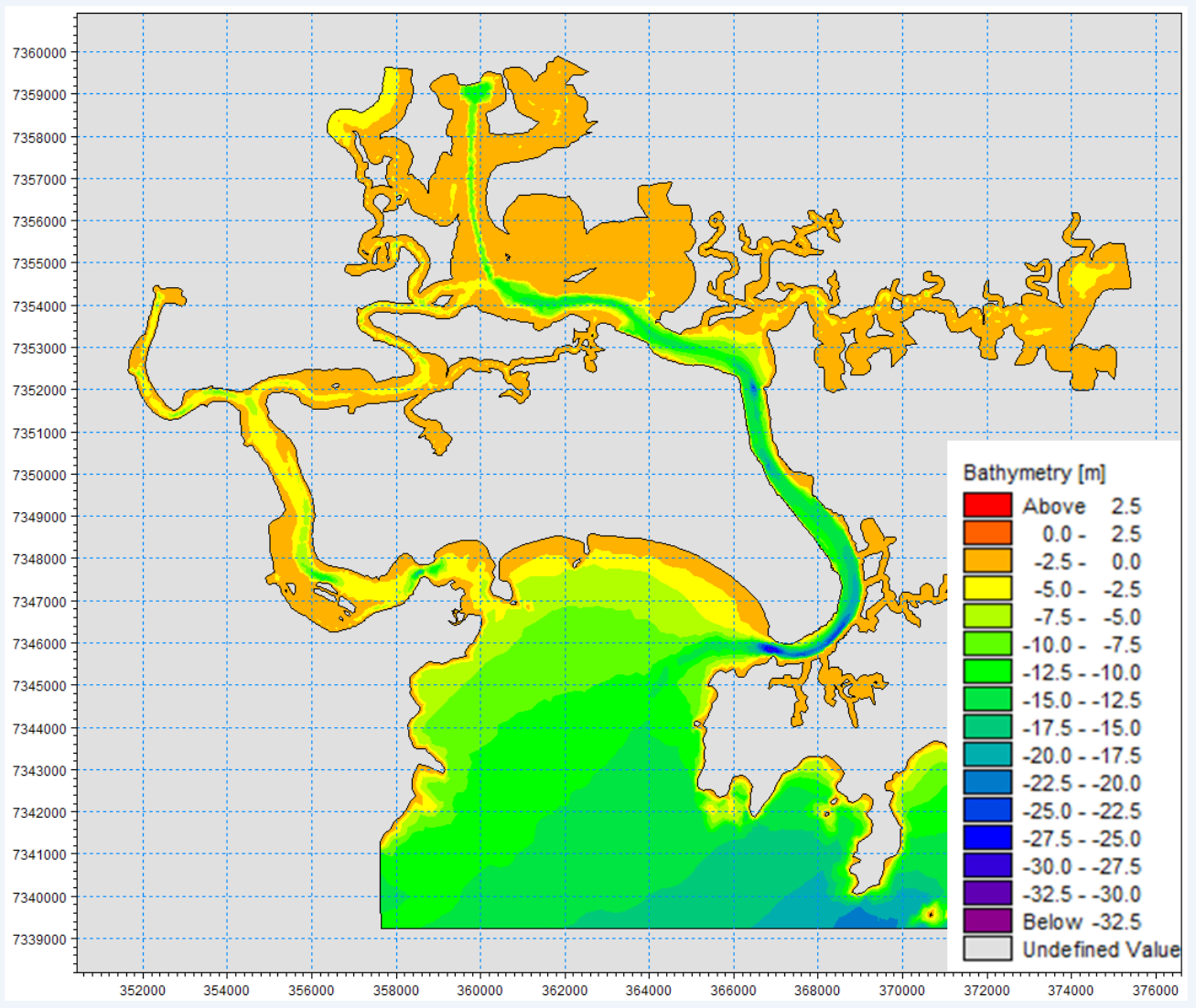

Figure 4. Bathymetric survey created to hydrodynamic modeling for Scenario 1.

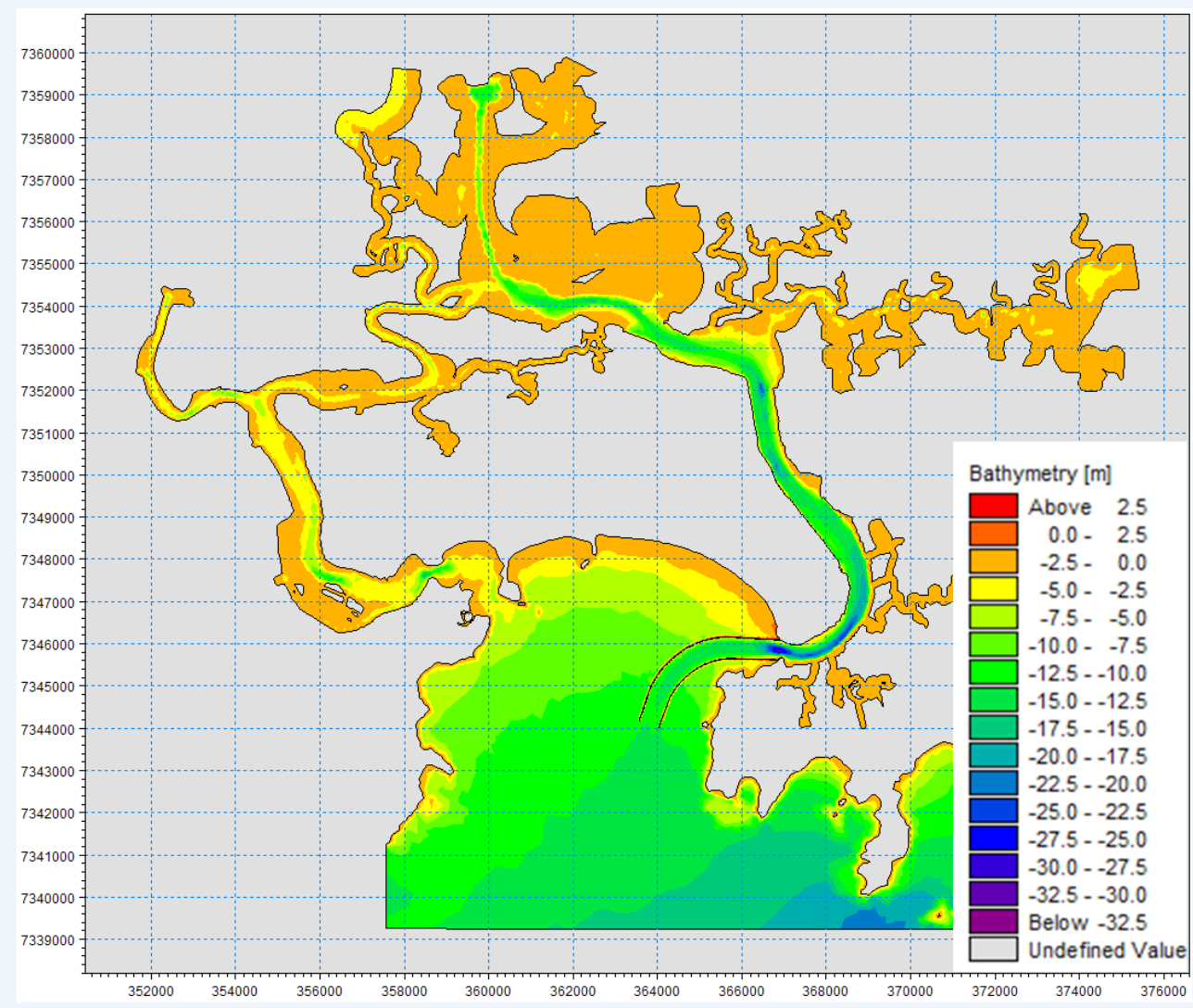

Figure 5. Bathymetric survey created to hydrodynamic modeling for Scenario 2. 


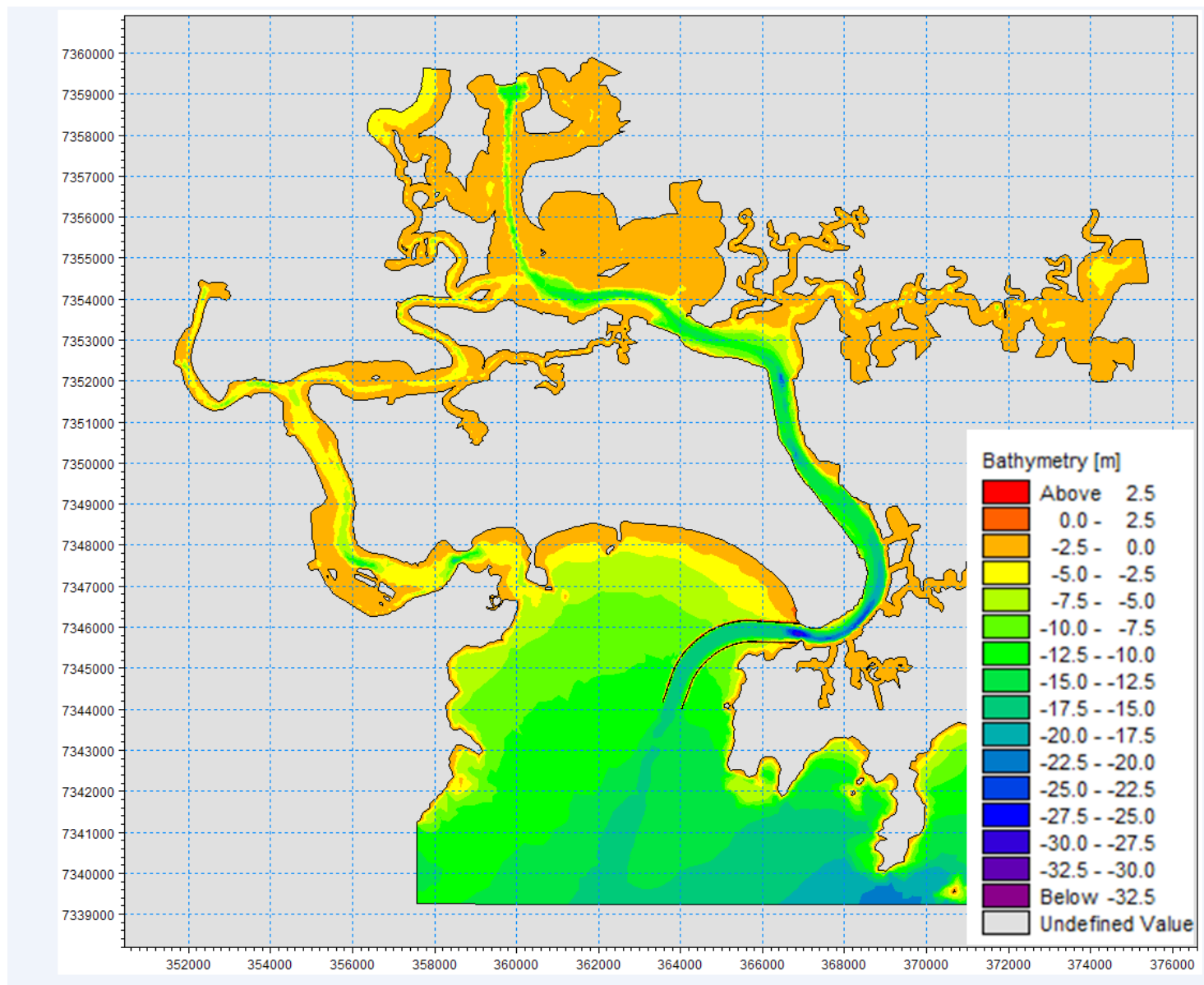

Figure 6. Bathymetric survey created to hydrodynamic modeling for Scenario 3.

there according to Sondotécnica (1977a). Harari and Camargo (1998) and Roversi et al. (2016) highlighted that reproducing tidal currents is enough to achieve good results in modeling numerically Santos Estuary, since the study target doesn't include evaluating meteorological effects.

In Brazil, unfortunately, there is a scarcity of recent hydrologic and oceanographic database. It's the main reason to use Sondotécnica (1977a) study, which is a complete report contained all necessary data to develop a modeling study.

The tidal levels used in the simulations were obtained from Sondotécnica (1977a) for a period between 08/23/76 and $08 / 26 / 76$ when the astronomical tide was about $1.3 \mathrm{~m}$ (high water spring). Also, all simulations have started 2 days before $08 / 23 / 76$ for numerical stabilization. The harmonic constituents used to obtain the tidal levels were extracted from Ilha da Moela' tide gauge which is near to the model boundary (see Figure 7).

The hydrodynamic model was calibrated from the propagation times of the tide in the Estuary based on Sondotécnica (1977a) data. Moreover, the main calibration parameter was the Manning number $(\mathrm{M}=1 / \mathrm{n})$. The calibration results are shown in Table 1 (SOUZA, 2012), in which " $d$ " is the delay in minutes of the high tide level passage between each two listed points.

The model was validated by comparing velocity profiles measured by Sondotécnica (1977b) and vertical integrated velocity extracted from the numerical modeling (SOUZA, 2012). Additionally, it was done a mesh and time step suitability verification which indicates the model was able for simulates the effects of environmental and anthropic changes along Santos Estuary (SOUZA, 2012).

\section{The efficiency in maintaining depths throughout the channel}

The methodology employed to evaluate the efficiency of the proposed jetties in maintaining depth was accomplished by an indirect form, using the measurement of the velocity of the current at 4 points along the axis of the channel (Figure 8), in three scenarios.

Point 1 was located in the estuary mouth and it was used as the reference point. The section in which this point is included naturally keeps depths of $28 \mathrm{~m}$ in the thalweg and depths greater than $17 \mathrm{~m}$ within the limits of the projected access channel.

Thus, the insertion of the jetties will be considered efficient if the current speed at the points 2, 3 and 4 becomes close to or higher than the speed obtained at the reference point.

The velocities extracted from simulations in conditions of mid ebb tide and mid flood tide were also compared with those obtained under similar conditions by Gireli et al. (2010) (Table 2). This comparison was done in order to increase the reliability of the results and to validate the numerical modeling developed in this study. 


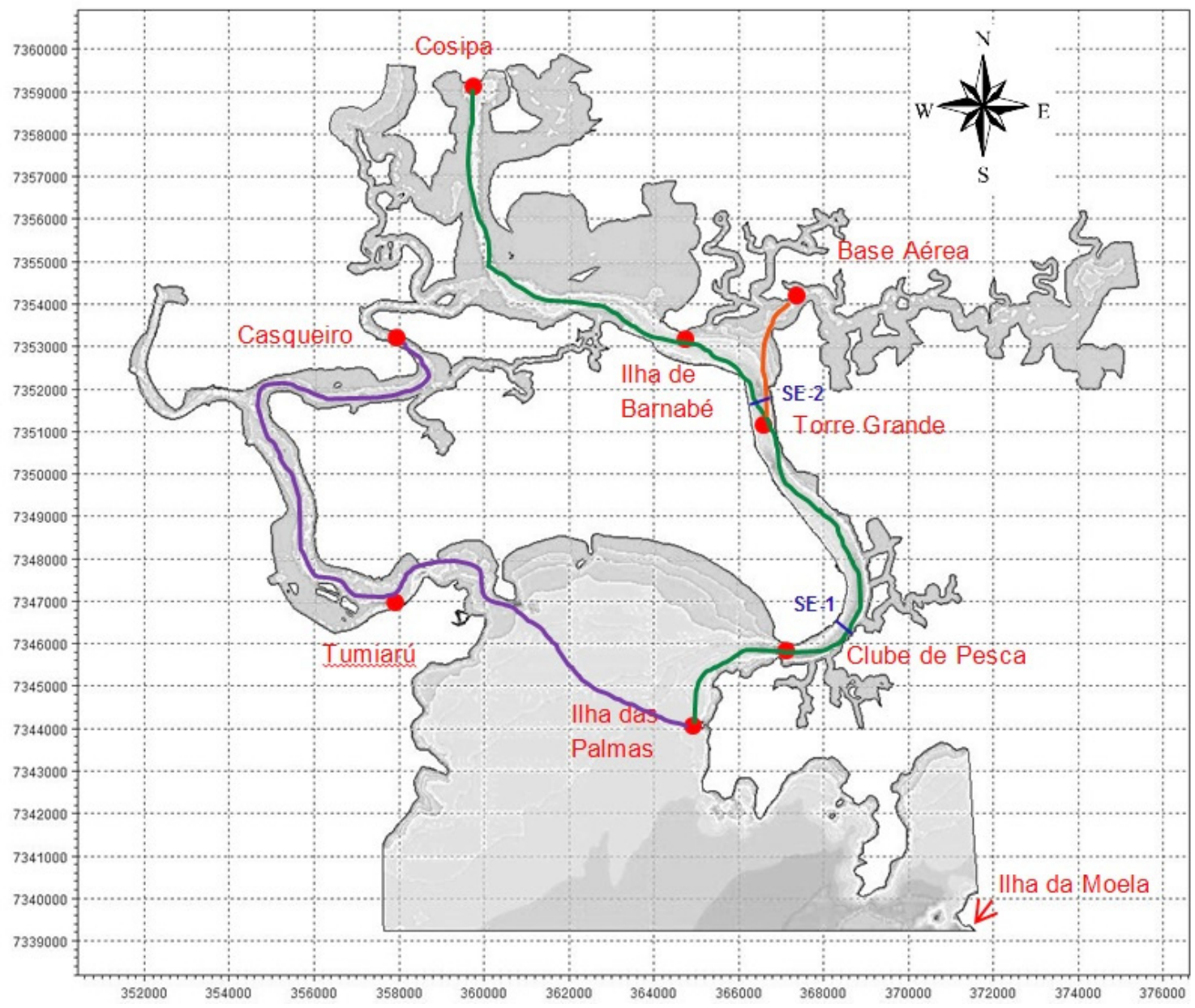

Figure 7. Tide Gauge positions. Green line (from Ilha das Palmas to Cosipa), Orange line (from Torre Grande to Base Aérea), purple line (from Ilha das Palmas to Casqueiro). Source: adapted from Sondotécnica (1977b).

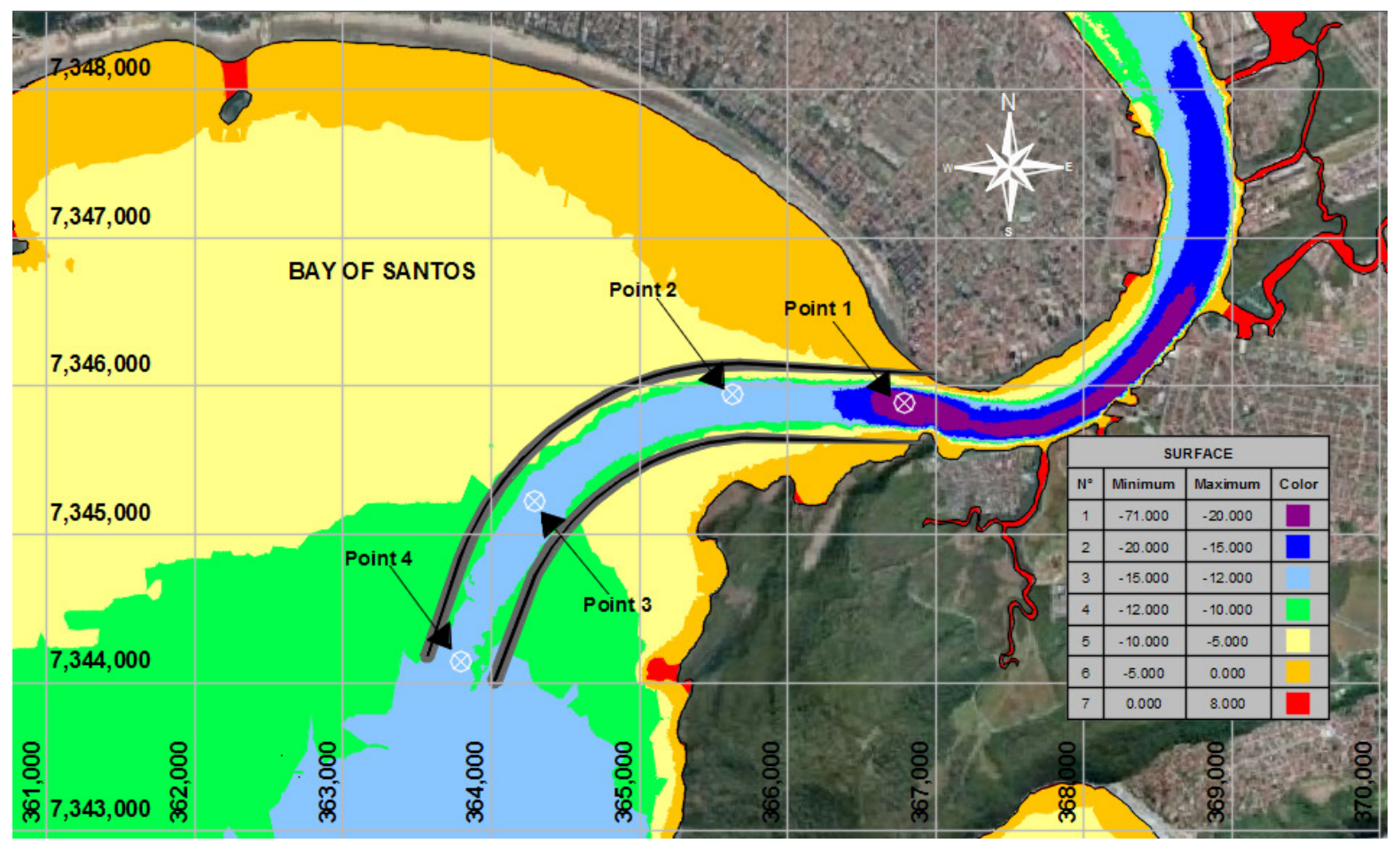

Figure 8. Position of the jetties and the observation points. 
Table 1. Model calibration results.

\begin{tabular}{|c|c|c|c|}
\hline \multirow[b]{2}{*}{ Tide gauge interval } & \multirow{2}{*}{$\frac{\text { Real data }}{\text { d (min) }}$} & \multicolumn{2}{|c|}{ Model data } \\
\hline & & $\begin{array}{c}\mathbf{M} \\
\left(\mathrm{m}^{1 / 3} / \mathrm{s}\right)\end{array}$ & $\mathrm{d}(\mathrm{min})$ \\
\hline $\begin{array}{l}\text { Ilha das Palmas - Clube de } \\
\text { Pesca }\end{array}$ & 10 & 35 & 10 \\
\hline $\begin{array}{l}\text { Clube de Pesca - Torre } \\
\text { Grande }\end{array}$ & 10 & 75 & 15 \\
\hline $\begin{array}{l}\text { Torre Grande - Ilha de } \\
\text { Barnabé }\end{array}$ & 12 & 20 & 9 \\
\hline Ilha de Barnabé - Cosipa & 18 & 25 & 21 \\
\hline Torre Grande - Base Aérea & 10 & 40 & 12 \\
\hline Ilha das Palmas - Tumiarú & 15 & 25 & 13 \\
\hline Tumiarú - Casqueiro & 35 & 20 & 31 \\
\hline
\end{tabular}

Source: Souza (2012).

Table 2. Comparison of surface velocities for the four measurement points before and after the inclusion of the jetties in the physical model.

\begin{tabular}{|c|c|c|c|c|}
\hline \multicolumn{2}{|c|}{$\begin{array}{l}\text { Method: } \\
\text { micro-rotor / confetti }\end{array}$} & \multirow{2}{*}{$\frac{\text { No Jetties }}{\begin{array}{c}\text { Velocity } \\
(\mathrm{m} / \mathrm{s})\end{array}}$} & \multirow{2}{*}{$\begin{array}{c}\text { Jetties } \\
\begin{array}{c}\text { Velocity } \\
(\mathrm{m} / \mathrm{s})\end{array}\end{array}$} & \multirow{2}{*}{$\begin{array}{c}\text { Results } \\
\text { speed } \\
\text { increase } \\
(\%)\end{array}$} \\
\hline Point & $\begin{array}{c}\text { Tide } \\
\text { condition }\end{array}$ & & & \\
\hline \multirow{2}{*}{1} & $1 / 2 \mathrm{~F}$ & 0.78 & 1.03 & 32 \\
\hline & $1 / 2 \mathrm{E}$ & 0.97 & 0.93 & -4 \\
\hline \multirow{2}{*}{2} & $1 / 2 \mathrm{~F}$ & 0.4 & 0.9 & 125 \\
\hline & $1 / 2 \mathrm{E}$ & 0.39 & 0.72 & 85 \\
\hline \multirow{2}{*}{3} & $1 / 2 \mathrm{~F}$ & 0.11 & 0.72 & 555 \\
\hline & $1 / 2 \mathrm{E}$ & 0.19 & 0.83 & 337 \\
\hline \multirow{2}{*}{4} & $1 / 2 \mathrm{~F}$ & 0.13 & 0.61 & 369 \\
\hline & $1 / 2 \mathrm{E}$ & 0.15 & 0.79 & 427 \\
\hline
\end{tabular}

Source: Adapted from Gireli et al. (2010).
It is noteworthy that Gireli et al. (2010) measured surface velocities by two techniques: using an optical micro-rotor coupled to a tachometer for velocities greater than $0.7 \mathrm{~m} / \mathrm{s}$ (prototype scale); and scattering confetti in the water and timing how long it took to travel $30 \mathrm{~cm}$ along the current trajectory centered in the respective point. This second technique was applied for slower velocities.

Furthermore, trajectories of virtual drifters were extracted from the numerical model. It was done during some tide cycles from the three scenarios to analyze the residual paths, and also the tendency of sediment dispersion to offshore, with the jetties introduction. The track flow visualization started in a mid-ebb tide and finished in a mid-flood tide after five ebb and flood tide.

\section{Effects of the jetties on the port channel estuarine area}

To evaluate the possible effects of jetties introduction on the estuarine channel, it was suggested a maximum discharge comparison between the proposed scenarios for two sections SE-1 and SE-2 (see Figure 7) in ebb and flood tide conditions.

Moreover, it were built maximum velocity difference maps near the mouth region for ebb and flood tide conditions, comparing the scenarios 2 and 3 with scenario 1 (reference).

\section{RESULTS AND DISCUSSION}

The comparison of the current velocities extracted from the four measurement points for the three scenarios in the model are shown in Figures 9 to 12.

Tables 3 and 4 show the comparison between the fastest velocities on mid ebb tide and mid flood tide extracted from Figures 9 to 12.

For the three scenarios, Point 1 keeps similar fastest velocities to $0,66 \mathrm{~m} / \mathrm{s}$, probably because this point is deeper than $17 \mathrm{~m}$ independently of the jetties introduction. However, at the other

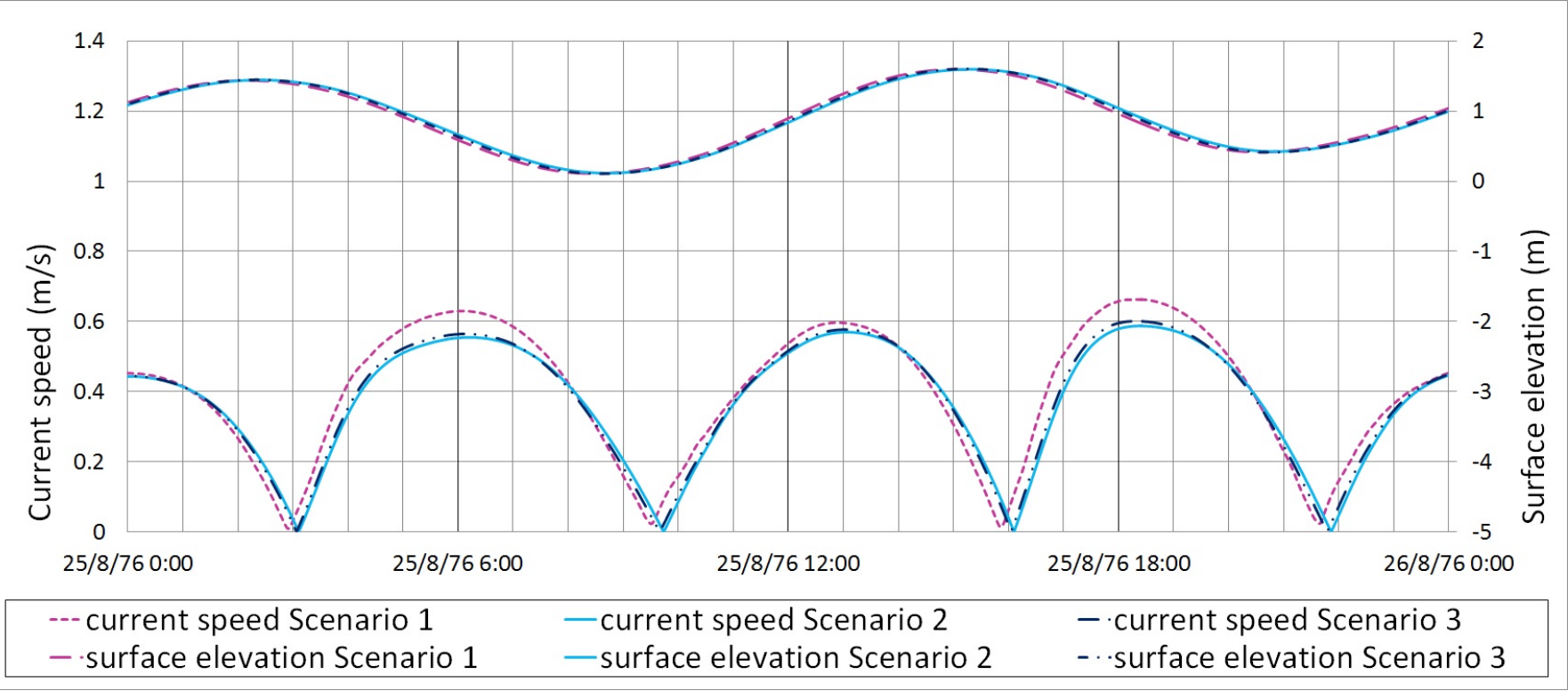

Figure 9. Comparison of surface velocities for the scenarios to Point 1. 


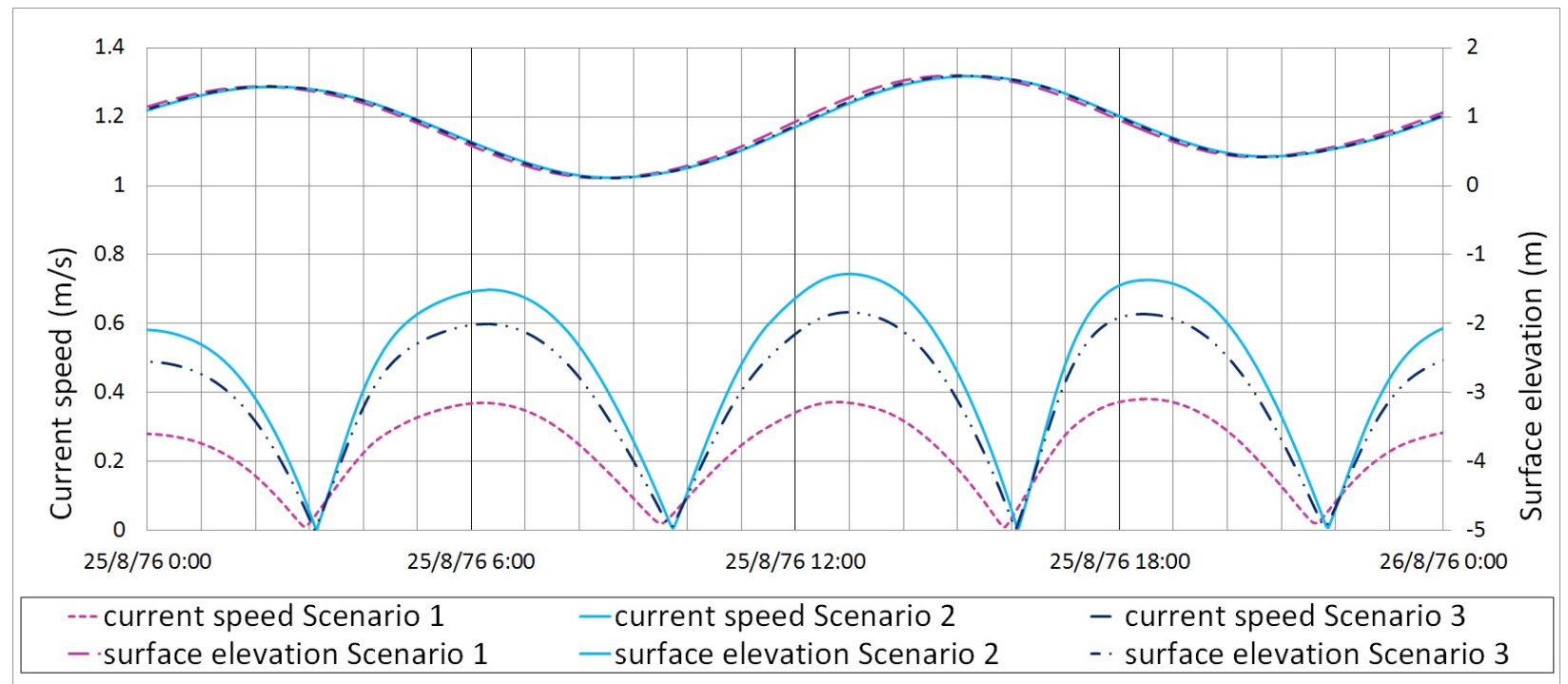

Figure 10. Comparison of surface velocities for the scenarios to Point 2.

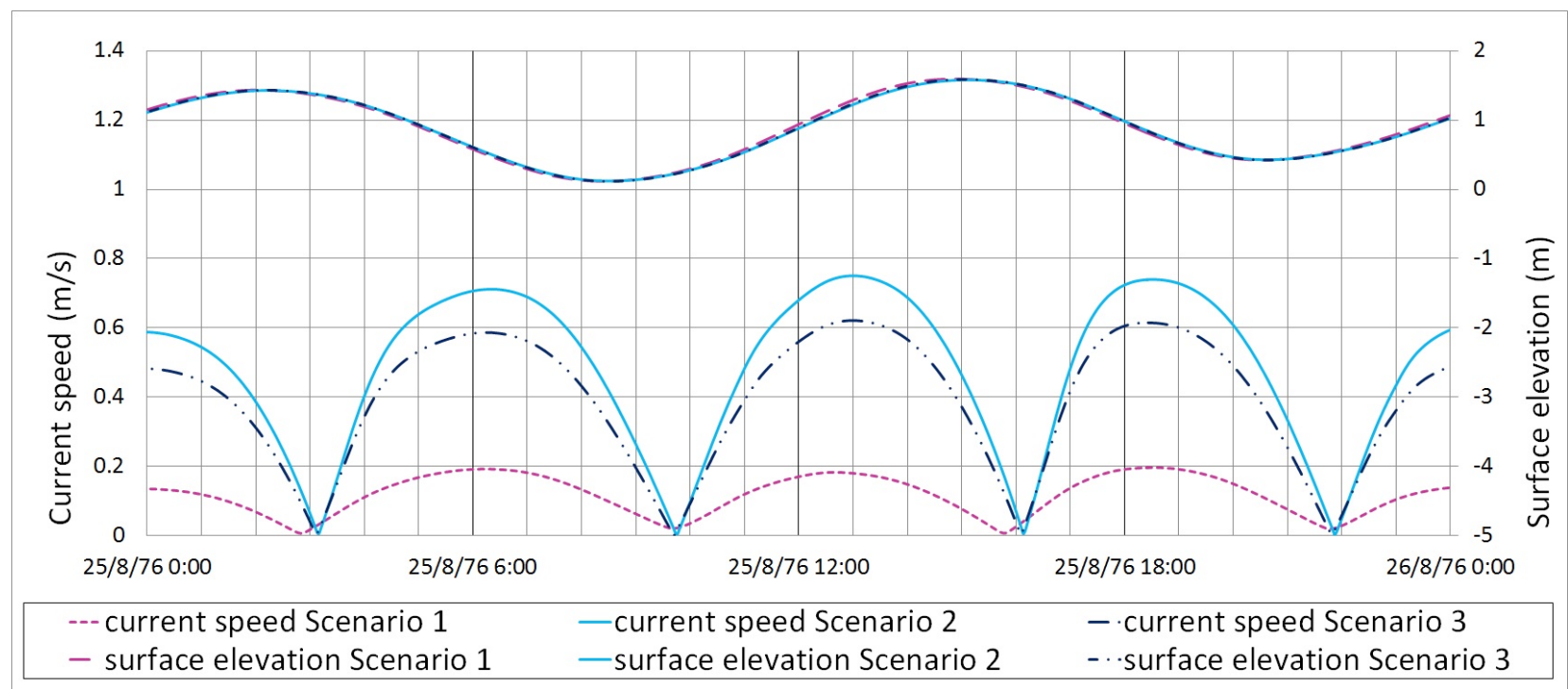

Figure 11. Comparison of surface velocities for the scenarios to Point 3.

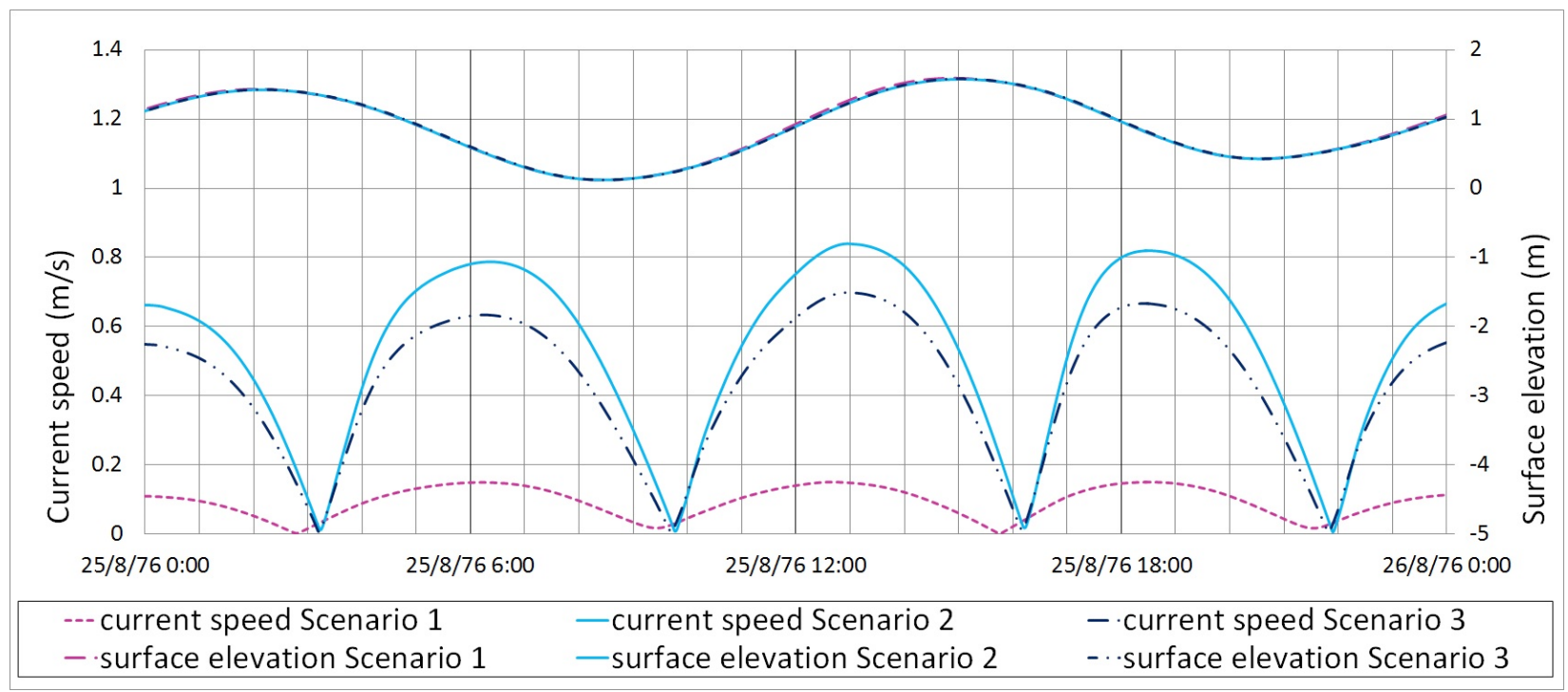

Figure 12. Comparison of surface velocities for the scenarios to Point 4. 
Table 3. Fastest velocities comparison: Scenarios 1 and 2.

\begin{tabular}{|c|c|c|c|c|}
\hline \multirow[b]{2}{*}{ Point } & \multirow[b]{2}{*}{$\begin{array}{c}\text { Tide } \\
\text { condition }\end{array}$} & \multirow{2}{*}{$\begin{array}{c}\text { Scenario } 1 \\
\text { Velocity } \\
(\mathrm{m} / \mathrm{s})\end{array}$} & \multirow{2}{*}{$\begin{array}{c}\text { Scenario } 2 \\
\text { Velocity } \\
(\mathrm{m} / \mathrm{s})\end{array}$} & \multirow{2}{*}{$\begin{array}{c}\text { Results } \\
\text { Speed } \\
\text { increase } \\
(\%)\end{array}$} \\
\hline & & & & \\
\hline \multirow{2}{*}{1} & 1/2 Flood & 0.60 & 0.58 & -3.3 \\
\hline & $1 / 2 \mathrm{Ebb}$ & 0.66 & 0.59 & -10.6 \\
\hline \multirow{2}{*}{2} & $1 / 2$ Flood & 0.37 & 0.74 & 100 \\
\hline & $1 / 2 \mathrm{Ebb}$ & 0.38 & 0.73 & 92 \\
\hline \multirow{2}{*}{3} & $1 / 2$ Flood & 0.18 & 0.75 & 317 \\
\hline & $1 / 2 \mathrm{Ebb}$ & 0.20 & 0.74 & 270 \\
\hline \multirow{2}{*}{4} & $1 / 2$ Flood & 0.15 & 0.84 & 460 \\
\hline & $1 / 2 \mathrm{Ebb}$ & 0.15 & 0.82 & 447 \\
\hline
\end{tabular}

Table 4. Fastest velocities comparison: Scenarios 1 and 3.

\begin{tabular}{cccccc}
\hline \multirow{2}{*}{ Point } & $\begin{array}{c}\text { Tide } \\
\text { condition }\end{array}$ & $\begin{array}{c}\text { Velocity } \\
(\mathbf{m} / \mathbf{s})\end{array}$ & $\begin{array}{c}\text { Selocity } \\
(\mathbf{m} / \mathbf{s})\end{array}$ & $\begin{array}{c}\text { Speed } \\
\text { increase } \\
\mathbf{( \% )}\end{array}$ \\
\hline \multirow{2}{*}{$\mathbf{1}$} & $1 / 2$ Flood & 0.60 & 0.58 & -3.3 \\
& $1 / 2$ Ebb & 0.66 & 0.60 & -9.1 \\
\hline \multirow{2}{*}{$\mathbf{2}$} & $1 / 2$ Flood & 0.37 & 0.63 & 70 \\
& $1 / 2$ Ebb & 0.38 & 0.63 & 66 \\
\hline \multirow{2}{*}{3} & $1 / 2$ Flood & 0.18 & 0.62 & 244 \\
& $1 / 2$ Ebb & 0.20 & 0.62 & 210 \\
\hline \multirow{2}{*}{4} & $1 / 2$ Flood & 0.15 & 0.70 & 367 \\
& $1 / 2$ Ebb & 0.15 & 0.67 & 347 \\
\hline
\end{tabular}

points, the velocities increased from $0.38 \mathrm{~m} / \mathrm{s}$ to at least $0.6 \mathrm{~m} / \mathrm{s}$ (until $0.84 \mathrm{~m} / \mathrm{s}$ ). It is noticeable that, with the construction of the jetties, the velocities at the other points would become close to the velocity at Point 1 .

Then, it can be inferred that, with the building of the proposed jetties, the maritime sandbar sector of the access channel would tend to naturally maintain depths greater than $17 \mathrm{~m}$, in the delimited region.

Now, comparing scenarios 2 and 3 , it is clear that the deepening of the navigation channel to $17 \mathrm{~m}$ and the consequent area increase would result in a decrease of the velocities, as expected.

Comparing numerical modeling results with those obtained from physical modeling (Table 5), the velocities measured in the physical model are, in most cases, closer than the ones obtained from numerical model, except by Point 1 in which the numerical modeling resulted in lower velocities, and by Points 3 in Scenario 1 and 4 in Scenario 2, in which numerical modeling resulted in greater velocities than physical modeling.

There are some factors that justify these differences, such as: the simulations on physical model did not include rivers flow; the numerical model is bi-dimensional and, therefore, the velocities are integrated along the vertical while in the physical model the velocities are measured on the surface; part of the velocities in the physical model were carried out using Lagrange method, while in the numerical model, Euler method was used;
Table 5. Physical and numerical modeling comparison.

\begin{tabular}{|c|c|c|c|c|c|c|c|}
\hline \multirow{3}{*}{ Point } & \multirow{3}{*}{$\begin{array}{c}\text { Tide } \\
\text { condition }\end{array}$} & \multicolumn{3}{|c|}{ Scenario 1} & \multicolumn{3}{|c|}{ Scenario 2} \\
\hline & & \multicolumn{2}{|c|}{$\begin{array}{c}\text { Velocity } \\
(\mathrm{m} / \mathrm{s})\end{array}$} & \multirow{2}{*}{$\begin{array}{l}\text { diff. } \\
(\%)\end{array}$} & \multicolumn{2}{|c|}{$\begin{array}{l}\text { Velocity } \\
(\mathrm{m} / \mathrm{s})\end{array}$} & \multirow{2}{*}{$\begin{array}{l}\text { diff. } \\
(\%)\end{array}$} \\
\hline & & P. M. & $\begin{array}{l}\text { N. } \\
\text { M. }\end{array}$ & & P. M. & $\begin{array}{l}\text { N. } \\
\text { M. }\end{array}$ & \\
\hline \multirow{2}{*}{1} & $1 / 2$ Flood & 0.78 & 0.6 & $-23 \%$ & 1.03 & 0.58 & $-44 \%$ \\
\hline & $1 / 2 \mathrm{Ebb}$ & 0.97 & 0.66 & $-32 \%$ & 0.93 & 0.59 & $-37 \%$ \\
\hline \multirow{2}{*}{2} & $1 / 2$ Flood & 0.4 & 0.37 & $-8 \%$ & 0.9 & 0.74 & $-18 \%$ \\
\hline & $1 / 2 \mathrm{Ebb}$ & 0.39 & 0.38 & $-3 \%$ & 0.72 & 0.73 & $1 \%$ \\
\hline \multirow{2}{*}{3} & $1 / 2$ Flood & 0.11 & 0.18 & $64 \%$ & 0.72 & 0.75 & $4 \%$ \\
\hline & $1 / 2 \mathrm{Ebb}$ & 0.19 & 0.2 & $5 \%$ & 0.83 & 0.74 & $-11 \%$ \\
\hline \multirow{2}{*}{4} & $1 / 2$ Flood & 0.13 & 0.15 & $15 \%$ & 0.61 & 0.84 & $38 \%$ \\
\hline & 1/2 Ebb & 0.15 & 0.15 & $0 \%$ & 0.79 & 0.82 & $4 \%$ \\
\hline
\end{tabular}

the physical model has a distorted scale, affecting the precision of the velocities measurement.

Notwithstanding, both models show a substantial increase of the velocities when the jetties are introduced, reinforcing the results' reliability.

In addition, from the Figures 13 to 15 are presented the trajectories of virtual drifters for the three scenarios.

From Scenario 1 (Figure 13), the drifters' tendency is to keep itself circulating in the bay. The same behavior was noticed by Sondotécnica (1977a) and Harari and Camargo (1998). However, from the scenarios 2 and 3 (Figures 14 and 15) it is noticed that the proposed jetties induced the drifters out of the bay. Assuming the current can induce the same behavior on the local sediment transport, it is clear that the jetties can expel the sediment out of the Port's channel, carrying the particles to the offshore direction.

Now, analyzing the effects of the jetties insertion on the estuary, it is presented on Figures 16 and 17 the comparison of maximum discharge between the proposed scenarios for two sections SE-1 and SE-2 in ebb and flood tide conditions.

From Tables 6 and 7 it is exemplified the maximum discharge difference obtained for the simulated period for ebb and flood conditions.

From Figures 18 to 21 it is presented the maximum velocity difference maps comparing Scenarios 2 and 3 with Scenario 1 for ebb and flood tide conditions.

Considering the simulated period, the jetties insertion led, in general, to a small decrease of discharge in the estuarine channel area and a small tide delay. At first, the discharge decrease is larger in SE-1 than SE-2, indicating that the jetties influence declines toward the interior of the estuary. Second, this effect is larger in flood tide than ebb tide condition. For example, the maximum difference obtained for the simulated period was $5.7 \%$ in flood and $4,1 \%$ in ebb tide condition (see Table 6 ). Third, the channel deepening (Scenario 3) minimizes the discharge reduction, in both flood and ebb tide conditions, reaching negligible values for ebb tide condition.

Furthermore, the velocity difference maps present a considerable increase of maximum velocity in the bay stretch of the channel over a small decrease in the estuarine stretch one of the channel, near to the mouth. Such as in the discharge comparison, the Figures 20 and 21 show a minimization of the velocity decrease 


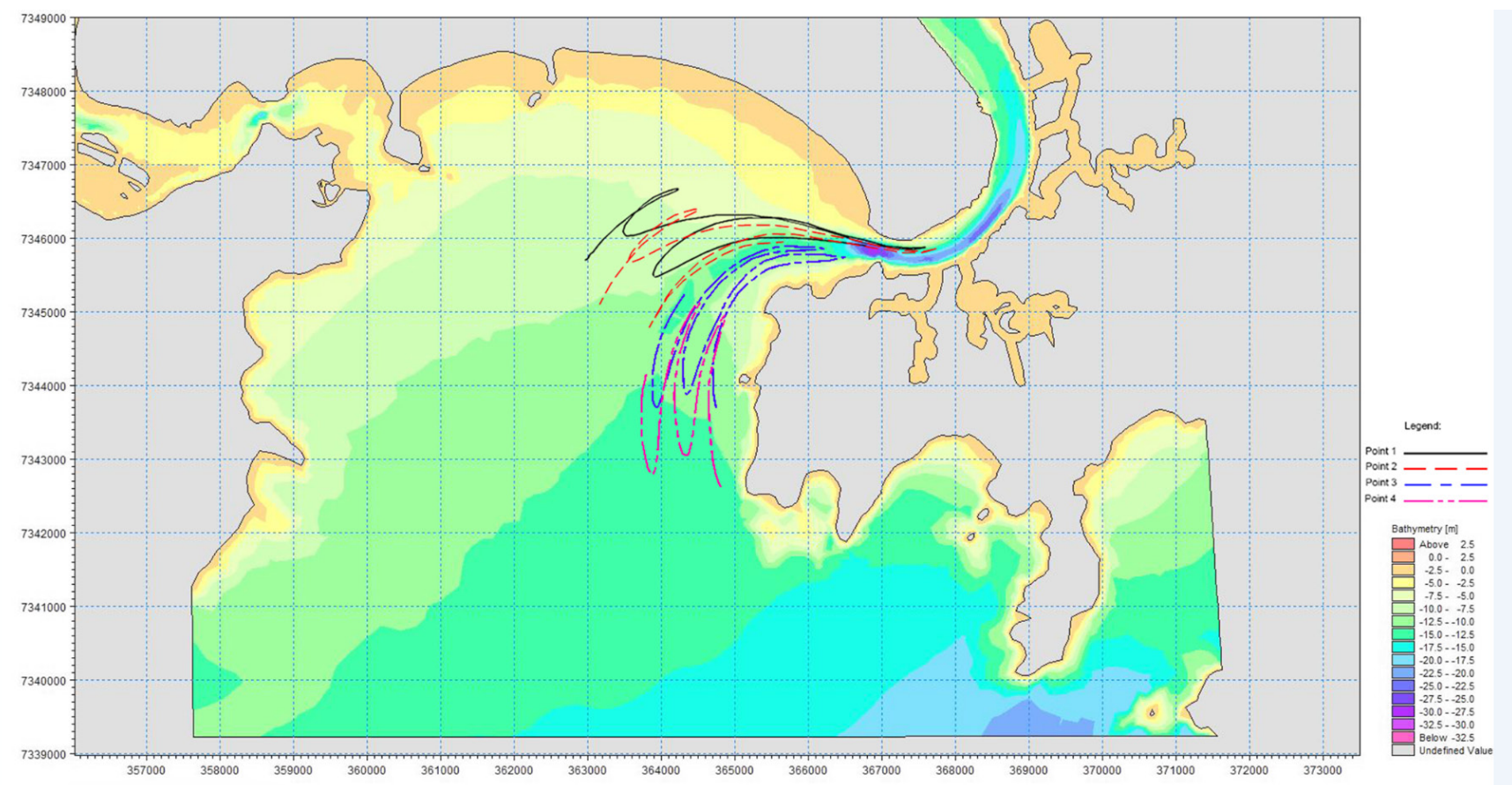

Figure 13. Comparison of trajectory of drifters to the measurement points for Scenario 1.

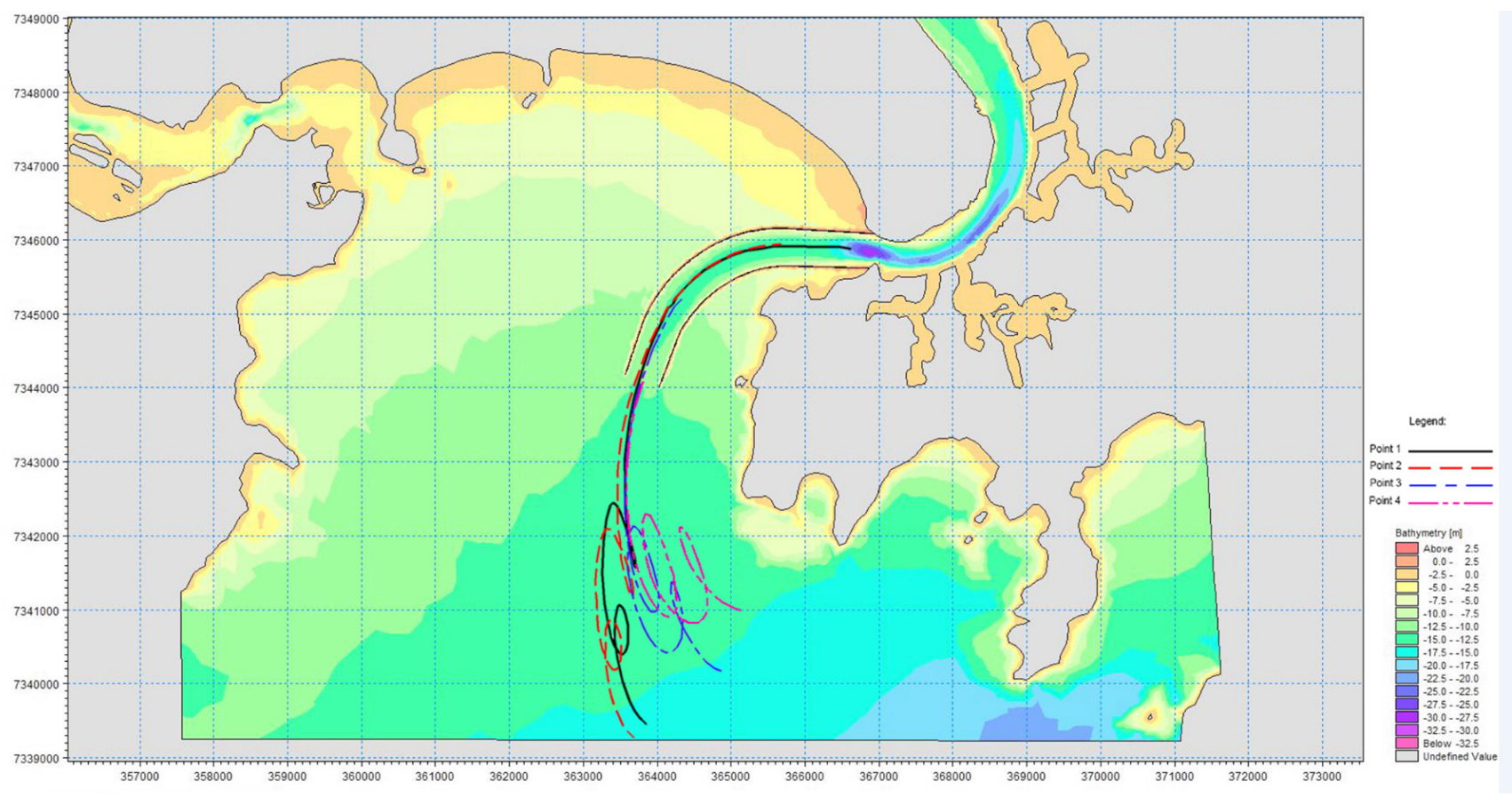

Figure 14. Comparison of trajectory of drifters to the measurement points for Scenario 2.

for Scenario 3, especially in the ebb tide condition (Figure 21) in which the velocity differences are smaller than $0,1 \mathrm{~m} / \mathrm{s}$ in the most part of the estuarine channel. It is highlighted that these maps were extracted for the tide cycle in which the greatest discrepancy between the scenarios were noted, considering the simulated period.
Considering that the ebb velocities are responsible for expel the sediments toward off-shore and these tide condition was the one whom was less affected by the jetties introduction, it is expected only small changes on the siltation rate for the estuarine stretch of the navigation channel. 


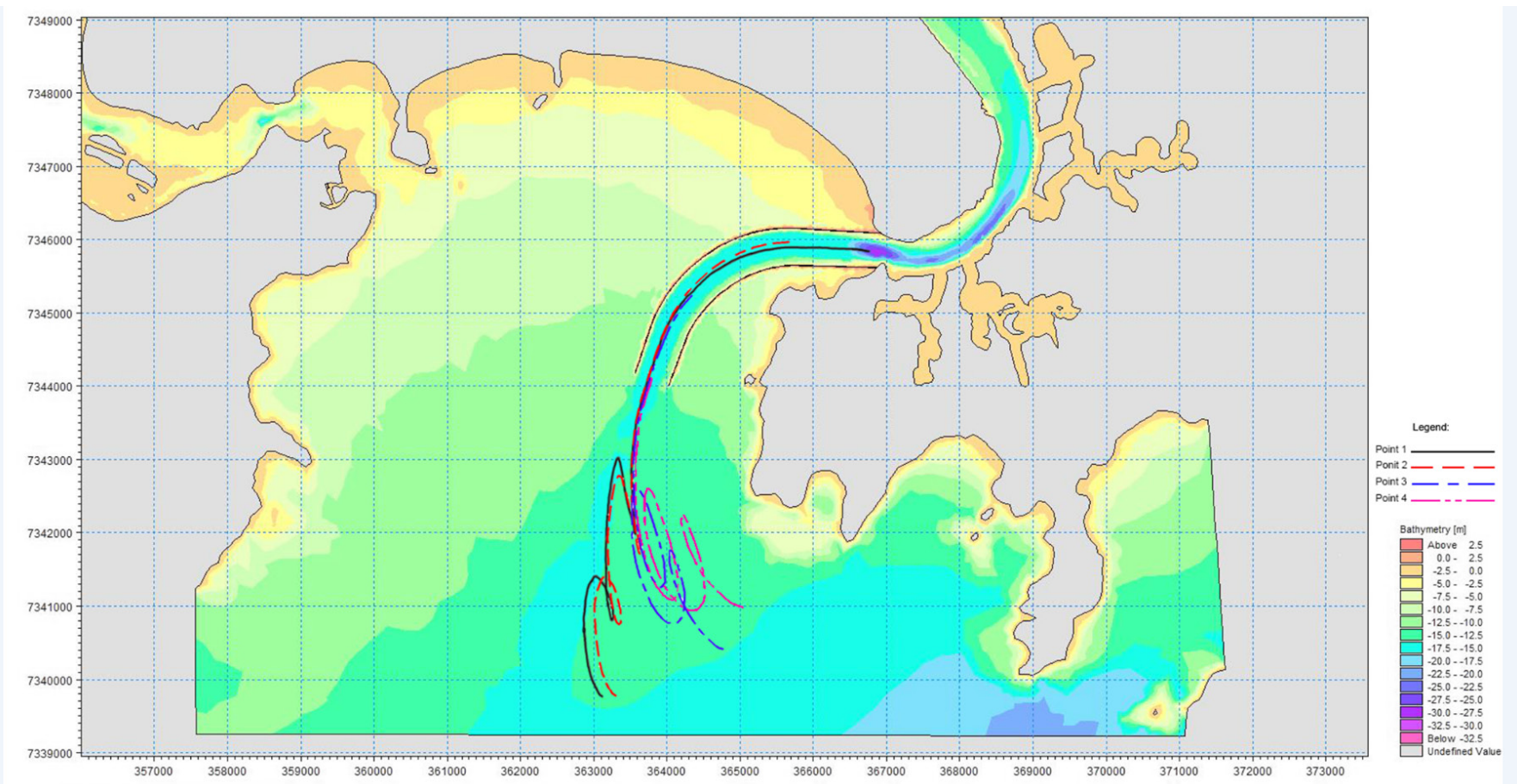

Figure 15. Comparison of trajectory of drifters to the measurement points for Scenario 3.

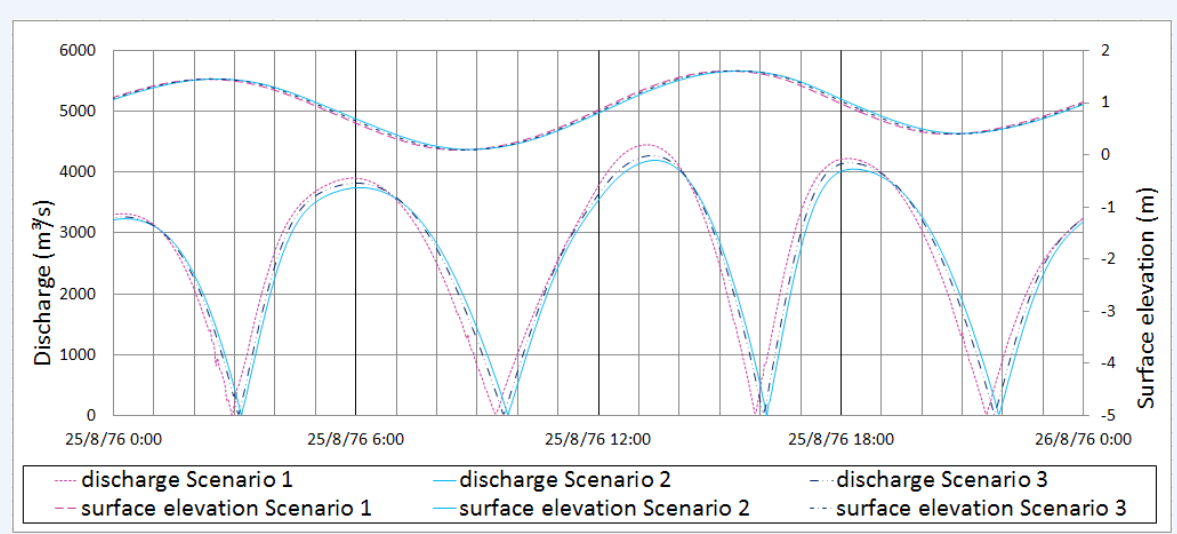

Figure 16. Discharge comparison between the three scenarios for SE-1.

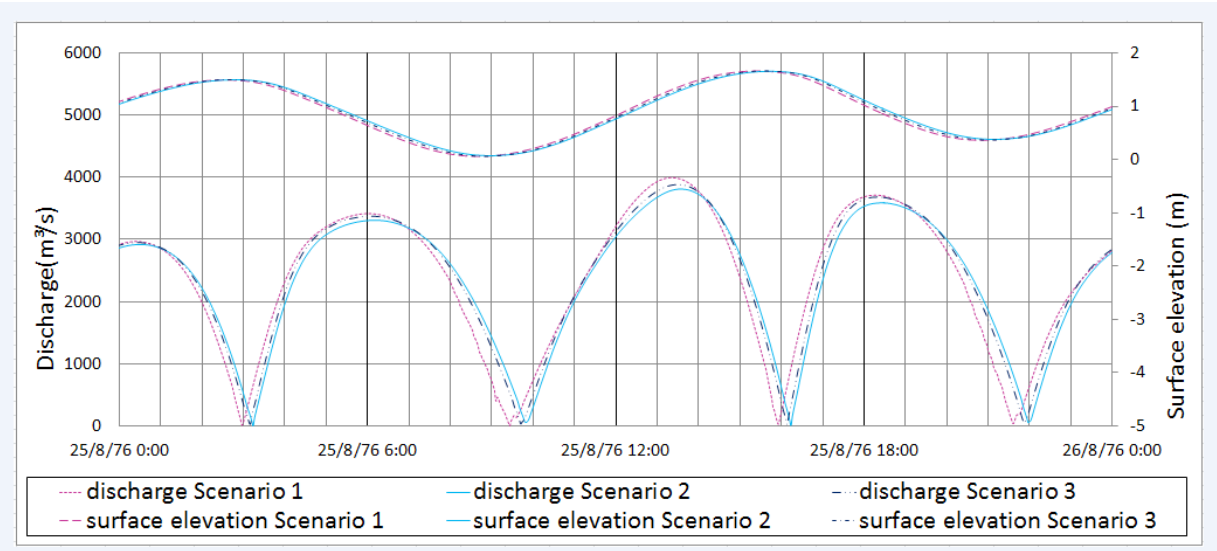

Figure 17. Discharge comparison between the three scenarios for SE-2. 


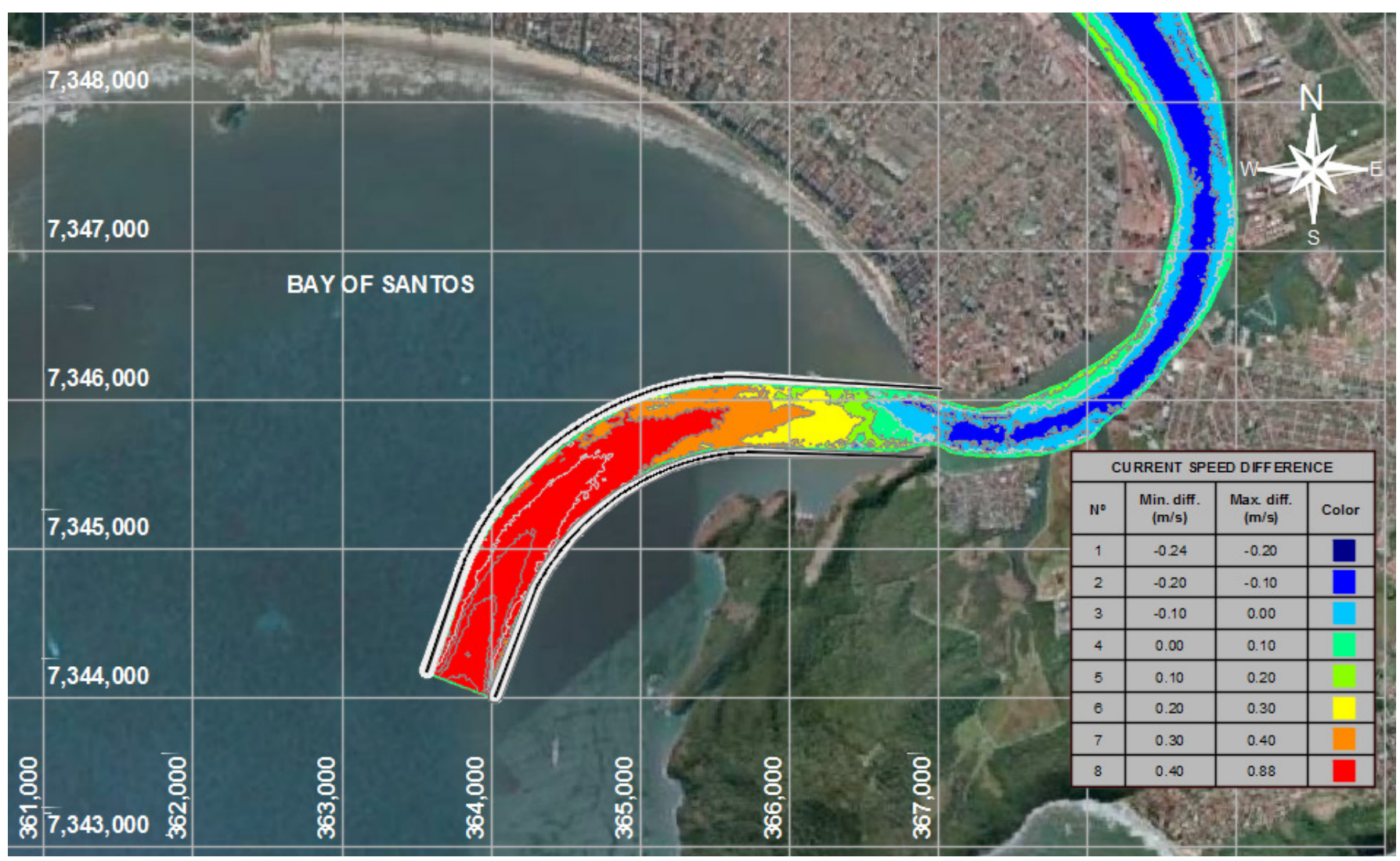

Figure 18. Maximum velocity difference map for flood tide condition comparing Scenario 2 with Scenario 1 (reference).

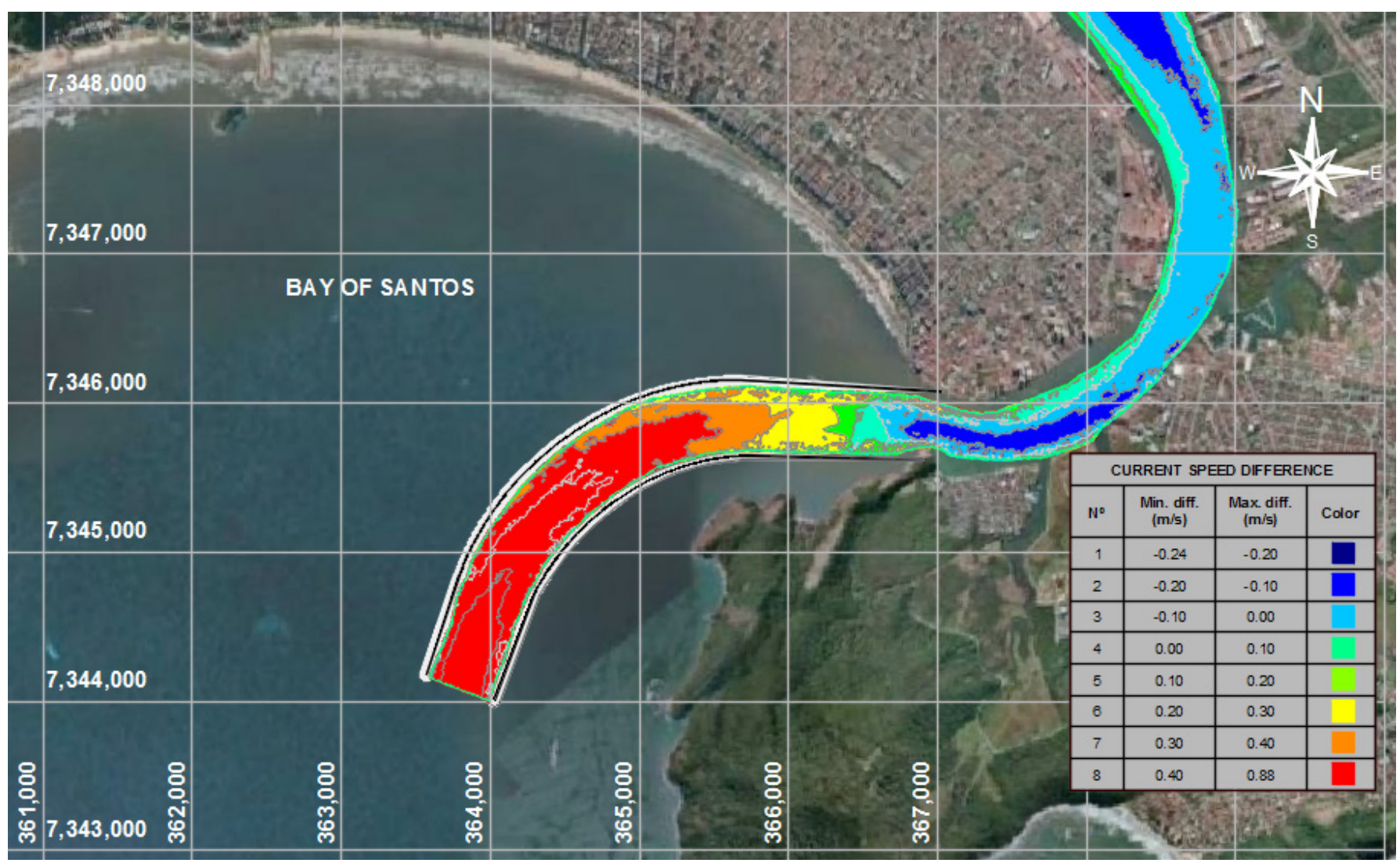

Figure 19. Maximum velocity difference map for ebb tide condition comparing Scenario 2 with Scenario 1 (reference). 


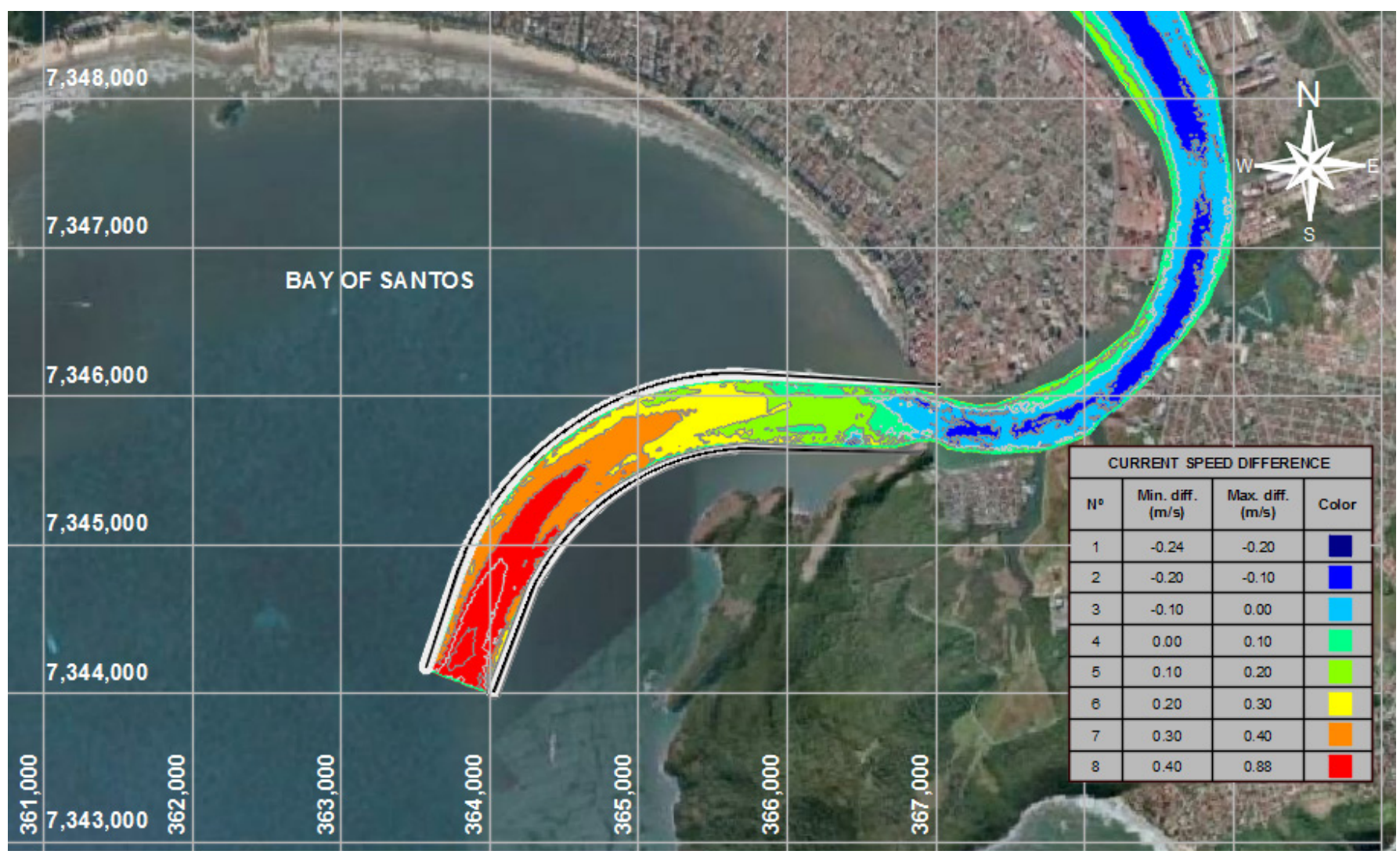

Figure 20. Maximum velocity difference map for flood tide condition comparing Scenario 3 with Scenario 1 (reference).

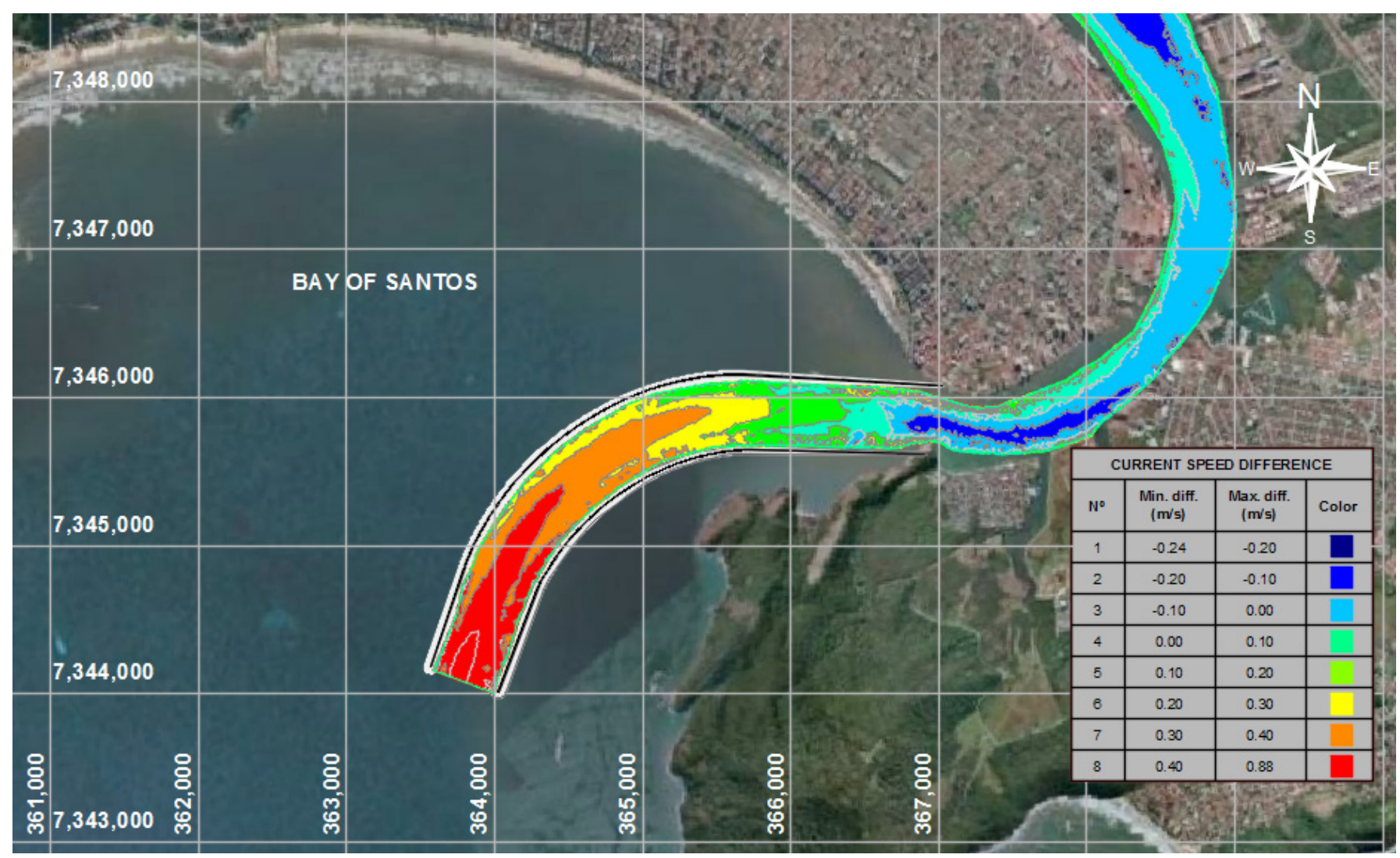

Figure 21. Maximum velocity difference map for ebb tide condition comparing Scenario 3 with Scenario 1 (reference). 
Table 6. Maximum discharge comparison for SE-1.

\begin{tabular}{|c|c|c|c|c|}
\hline SE-1 & $\begin{array}{c}\text { Maximum } \\
\text { Discharge } \\
\text { Flood }\left(\mathrm{m}^{3} / \mathrm{s}\right)\end{array}$ & $\begin{array}{c}\text { Diff. } \\
(\%)\end{array}$ & $\begin{array}{c}\text { Maximum } \\
\text { Discharge } \\
\text { Ebb }\left(\mathrm{m}^{3} / \mathrm{s}\right)\end{array}$ & $\begin{array}{c}\text { Diff. } \\
(\%)\end{array}$ \\
\hline Scenario 1 & $4,451.8$ & ref. & $4,225.4$ & ref. \\
\hline Scenario 2 & $4,196.4$ & $-5,7 \%$ & $4,051.7$ & $-4.1 \%$ \\
\hline Scenario 3 & $4,274.1$ & $-4,0 \%$ & $4,156.4$ & $-1.6 \%$ \\
\hline
\end{tabular}

Table 7. Maximum discharge comparison for SE-2.

\begin{tabular}{|c|c|c|c|c|}
\hline SE-2 & $\begin{array}{c}\text { Maximum } \\
\text { Discharge } \\
\text { Flood }\left(\mathrm{m}^{3} / \mathrm{s}\right)\end{array}$ & $\begin{array}{c}\text { Diff. } \\
(\%)\end{array}$ & $\begin{array}{c}\text { Maximum } \\
\text { Discharge } \\
\text { Ebb }\left(\mathrm{m}^{3} / \mathrm{s}\right)\end{array}$ & $\begin{array}{c}\text { Diff. } \\
(\%)\end{array}$ \\
\hline Scenario 1 & $3,994.2$ & ref. & $3,713.5$ & ref. \\
\hline Scenario 2 & $3,811.1$ & $-4.6 \%$ & $3,588.8$ & $-3.4 \%$ \\
\hline Scenario 3 & $3,884.1$ & $-2.8 \%$ & $3,681.9$ & $-0.9 \%$ \\
\hline
\end{tabular}

\section{CONCLUSION}

Considering the hydrological and morphological databases applied in this study are still valid and also that the salinity and temperature stratification could be neglected, Santos' hydrodynamic model could be successfully developed and calibrated using the tidal and river flow field data available. The numerical model has also allowed simulating the introduction of the proposed jetties, comparing its effect with that observed in physical modeling. Moreover, it was possible to evaluate the effect of jetties after the deepening dredging of the channel, which was not possible on the fixed bottom physical model.

The proposed jetties are a different solution since they are curved and slightly convergent rather than rectilinear and strongly convergent as recommended by Pezzoli et al. (2013), whose is the most recent proposal.

The alternative studied here has been shown efficient in terms of depth maintenance in the bay stretch of the channel. It is clear when comparing the speed of currents with and without the proposed jetties. The introduction of the structures accelerates the flow at points 2, 3 and 4 , showing the tendency that the sea bed between the jetties would be deepened naturally.

The fact that two different methodologies (physical and numerical modeling) have reached the same conclusion certainly increases the reliability of the results obtained and of the calibration of the numerical model used in this study.

Regarding residual paths, although the proposed jetties are not strongly convergent, their presence enhance the effect of the ebb current and cause a clear sediment dispersion tendency to offshore, and hence the maintenance of depth and decreasing the predicted dredging volume.

Notwithstanding, there is a small discharge and velocity decrease in the estuarine stretch of the channel with the jetties insertion. This effect is minimal in Scenario 3, which is the final channel design, especially considering the ebb tide condition, which is responsible for cleaning the channel expelling sediment to offshore.

It is important to highlight that the jetties studied here are huge structures that may cause significant impacts on the adjacent beaches. So, future studies aim to introduce the effects of waves and winds in the bay making possible to evaluate these effects. Moreover, it is pretty important evaluate the changes, in quantitative terms, on the siltation rate aiming to know if the decrease of the maintenance dredging volume in the bay compensates the possible increase of the dredged volume in the estuarine stretch of the channel.

Finally, despite the necessity of complementary studies to refine the jetties layout, the results presented here show that the proposed curved and slightly convergent jetties cause a significant increase in the bay stretch of the navigation channel, making them a potential solution to the maintenance of depths as 17 meters. It means, it would be more efficient having the desired depth with proposed jetties than without them to enable the access of the Post-Panamax ships and ensuring Santos as the hub port of South America.

\section{ACKNOWLEDGEMENTS}

The authors thank DHI for providing a time limited license for thesis of Mike 21 FM software. This license allowed the whole study and consequently this paper.

\section{REFERENCES}

BAPTISTELLI, S. C. Análise crítica da utilização de modelagem matemática na avaliação da dispersão de efluentes leves no litoral da Baixada Santista (Estado de São Paulo). 2008. 314 f. Tese (Doutorado em Engenharia Hidráulica) - Escola Politécnica, Universidade de São Paulo, São Paulo, 2008. http://dx.doi.org/10.11606/T.3.2008. tde-24112008-150611. $</$ ths $>$.

BRASIL. Secretaria de Portos. Sistema Portuário Nacional. Brasília, 2015. Available from: <http://www.portosdobrasil.gov.br/>. Access on: 28 nov. 2015.

CNT - CONFEDERAÇÃO NACIONAL DO TRANSPORTE. Pesquisa CNT do transporte marítimo. Brasília, 2015. Available from: <http://www.cnt.org.br/pesquisamaritima/files/pesquisa_ maritima_2012.pdf $>$. Access on: 03 nov. 2015.

CODESP - COMPANHIA DOCAS DO ESTADO DE SÃO PAULO. (Org.). Porto de Santos supera movimentação prevista para 2012. Santos, 2015. Available from: <http://www.portodesantos.com. br $/$ pressRelease.php?idRelease $=650>$. Access on: 30 oct. 2015 .

CODESP - COMPANHIA DOCAS DO ESTADO DE SÃO PAULO. (Org.). Santos sobe em ranking internacional de movimentação de contêineres. Santos, 2016. Available from: <http://www.portodesantos. com.br/pressRelease.php?idRelease $=795>$. Access on: 28 jan. 2016 .

CTH - CENTRO TECNOLÓGICO DE HIDRÁULICA. Relatório das atividades da missão bidrográfica de Santos para a COPLAT. São Paulo, 1968.

CTH - CENTRO TECNOLÓGICO DE HIDRÁULICA. Relatório final dos estudos de recuperação e proteção da Praia de São Vicente. São Paulo, 1976. 
DHI - DANISH HYDRAULIC INSTITUTE. MIKE FM HD 2D - MIKE 21 flow model FM. Hydrodynamic module. User guide. Dinamarca, 2011.

G1 SANTOS. MPF entra com ação para conter erosão em praias de Santos, SP. Santos, 2015. Available from: <http://g1.globo.com/sp/ santos-regiao/noticia/2015/06/mpf-entra-com-acao-para-contererosao-em-praias-de-santos-sp.html>. Access on: 05 out 2016.

GIRELI, T. Z.; RINKE, L. G.; ZANETTTI, S. H. Estudo em modelo reduzido de molhes guia-corrente para o Porto de Santos - São Paulo - Brasil, 09/2012. In: CONGRESO LATINOAMERICANO DE HIDRÁULICA, 24., 2010, Punta Del Leste, Uruguai. Anais... Punta Del Leste: IAHR, 2010. v. 1, p. 1-10.

GIRELI, T. Z.; VENDRAME, R. F. Aprofundamento do Porto de Santos: uma análise crítica. Revista Brasileira de Recursos Hídricos, v. 17, n. 3, p. 49-59, 2012.

HARARI, J.; CAMARGO, R. Modelagem numérica da região costeira de Santos (SP): circulação de maré. Revista Brasileira de Oceanografia, v. 46, n. 2, p. 135-156, 1998.

PEZZOLI, A.; ALFREDINI, P.; ARASAKI, E.; ROSSO, M.; SOUZA JUNIOR, W. C. Impacts of climate changes on management policy of the harbors, land areas and wetlands in the São Paulo state coastline (Brazil). Journal of Climatology \& Weather Forecasting, v. 1, n. 2, p. 1-7, 2013. http://dx.doi.org/10.4172/2332-2594.1000101.

REIS, L. F. B. Estudo em modelo redurido de fundo móvel do Porto de Santos. Rio de Janeiro: INPH, 1978. Apresentado no $1^{\circ}$ ciclo de palestras de Engenharia Costeira.
ROVERSI, F; ROSMAN, P. C. C.; HARARI, J. Análise das trajetórias das águas continentais afluentes ao sistema Estuarino de Santos. Revista Brasileira de Recursos Hídricos, v. 21, n. 1, p. 242-250, 2016.

SCHWAB, K. The Global Competitiveness Report 2015-2016. Geneva: World Economic Forum, 2015. 384 p. Available from: <http:// www3.weforum.org/docs/gcr/2015-2016/Global_Competitiveness_ Report_2015-2016.pdf>. Access on: 20 sept. 2016.

SONDOTÉCNICA. Comportamento hidráulico e sedimentológico do Estuário Santista. Brasília: Empresas de Portos do Brasil S.A. Portobrás; Instituto de Pesquisas Hidroviárias - INPH, 1977a. Relatório Final - Texto.

SONDOTÉCNICA. Comportamento hidráulico e sedimentológico do Estuário Santista. Brasília: Empresas de Portos do Brasil S.A. Portobrás; Instituto de Pesquisas Hidroviárias - INPH, 1977 b. Relatório Final - Desenhos.

SOUZA, C. M. M. A. Caracterização hidrodinâmica da Baía e Estuário Santista utilizando a modelagem numérica. 2012. 123 f. Dissertação (Mestrado em Recursos Hídricos, Energéticos e Ambientais) Curso da Faculdade de Engenharia Civil, Arquitetura e Urbanismo, Universidade Estadual de Campinas, Campinas, 2012.

SOUZA, C. M. M. A.; GIRELI, T. Z. Caracterização hidrodinâmica da Baía e Estuário Santista utilizando a modelagem numérica 11/2010. In: CONGRESO LATINOAMERICANO DE HIDRÁULICA, 25., 2012, San Jose, Costa Rica. Anais... San Jose: IAHR, 2012. v. 1, p. 1-10. 